\begin{tabular}{|c|c|c|}
\hline Beitr. Ent. & Keltern & ISSN 0005-805X \\
\hline $\mathbf{6 2}(2012) 1$ & S. $103-124$ & 15.05 .2012 \\
\hline
\end{tabular}

\title{
Cephalic labial gland secretions of males as species recognition signals in bumblebees: are there really geographical variations in the secretions of the Bombus terrestris subspecies?
}

\section{(Hymenoptera: Apidae: Bombus)}

With 3 figures and 5 tables

\section{Andreas Bertsch and Horst Schweer}

\begin{abstract}
Zusammenfassung
Um künstliche Kolonien zu züchten und frische Männchen zu bekommen, wurden Frühjahrsköniginnen der Unterarten von Bombus terrestris gefangen (B. terrestris audax, B. t. canariensis, B. t. maderensis, B. t. terrestris and B.t.dalmatinus). Zusätzlich wurden Männchen von B.t.lusitanicus in Portugal, B.t.terrestris in Südfrankreich und Deutschland, B. t.xanthopus auf Korsika und B. t. sassaricus auf Sardinien im Freiland gefangen. Die männlichen Labialdrüsensekrete von 18 Proben wurden mittels Gaschromatographie / Massenspektrometrie untersucht. Etwa 70 Substanzen wurden identifiziert, eine Mischung azyklischer Sesquiund Diterpene (Alkohole, Aldehyde, Azetate und Ester) und verschiedene geradkettige Fettsäurederivate (Alkohole, Aldehyde, Azetate, Ester und gesättigte sowie ungesättigte Kohlenwasserstoffe $C_{21}-C_{29}$ ). Die Hauptkomponente in allen Proben war 3,7,11-Trimethyldodeca-(6E),10-dien-1-ol (2,3-Dihydrofarnesol), einige wenige Freilandproben enthielten zum Teil beträchtliche Mengen an Estern (wohl im Zusammenhang mit der Alterung der Männchen), vor allem 3,7,11-Trimethyldodeca-(6E),10-dien-1-yl-dodecanoat, und da diese wohl nicht für die Kommunikation geeigneten Substanzen die prozentuale Peak Fläche der übrigen Substanzen absenkt und so den Vergleich zwischen den verschiedenen Proben erschwert, wurden alle Substanzen mit einer Molmasse größer als Heptacosan $\left(C_{27}\right.$ Kohlenwasserstoff) bei der Auswertung ausgeschlossen. Mit Ausnahme der Proben B. t. xanthopus von Korsika und B. t. sassaricus von Sardinien, denen das in den übrigen Proben mit etwa 10 \% Peak Fläche enthaltene Ethyldodecanoat vollständig fehlt, gibt es keine bemerkenswerte geographische Variation. Die Variabilität in der Zusammensetzung der Labialdrüsensekrete von (1) einzeln gemessenen Männchen aus derselben Kolonie, von (2) Proben geographisch benachbarter Fundorte und von (3) Proben geographisch weit entfernter Fundorte ist in derselben Größenordnung. Diese Befunde werden im Vergleich mit abweichenden veröffentlichten Befunden diskutiert. Wegen ihrer geringen Variabilität auch über große geographische Distanz sind die Labialdrüsensekrete von $B$. terrestris als Art-Erkennungs-Signale gut geeignet.
\end{abstract}

\section{Summary}

In order to grow artificial colonies and to obtain fresh males, spring queens of Bombus terrestris subspecies (B. terrestris audax, B. t. canariensis, B. t. maderensis, B. t. terrestris and B. t. dalmatinus) were collected from different localities. In addition, males of $B$. terrestris lusitanicus from Portugal, $B$. t. terrestris from southern France and Germany, B. t. xanthopus from Corsica and B. t. sassaricus from Sardinia were collected in the field. Cephalic labial gland secretions of 18 specimens were analysed by gas chromatography/mass spectrometry (GC/MS). About 70 compounds were identified: a mixture of acyclic sesqui- and diterpenes (alcohols, aldehydes, acetates) and various straight-chain fatty acid derivatives (alcohols, aldehydes, esters, and both saturated and unsaturated hydrocarbons with $\mathrm{C}_{21}-\mathrm{C}_{29}$ ). The main component in all specimens was 3,7,11-trimethyldodeca-(6E),10-dien-1-ol (2,3-dihydrofarnesol). A few specimens from the field collections 
also contained considerable amounts of esters (connected to the aging of males), particularly 3,7,11-trimethyldodeca-(6E),10-dien-1-yl dodecanoate and, as these compounds (not involved in communication) decreased the peak area percentages and made comparisons difficult, all substances with a molecular mass larger than heptacosane $\left(\mathrm{C}_{27}\right.$ hydrocarbon $)$ were excluded from the analysis. With the exception of specimens of B. t.xanthopus from Corsica and B.t. sassaricus from Sardinia, which were devoid of ethyl dodecanoate (available in all of the other specimens at about $10 \%$ of the peak area), no significant geographical variability was observed. The variability in the pattern of substances of each of (1) single males from the same colony, (2) specimens from the same geographical region, and (3) specimens from localities separated by a large geographical distance was within the same order of magnitude. These findings are discussed and compared with differences found in other published results. Because of their low variability and stability over large geographical distances, labial gland secretions of $B$. terrestris are very well suited to functioning as 'species recognition' signals.

\section{Introduction}

Flight path activity and scent marking has long been observed for many bumblebee species, and male cephalic labial gland secretions have been investigated in great detail (BERGSTRÖm et al. 1981; Valterová \& Urbanová 1997). The compositions of male labial gland secretions are species specific and the secretions are often treated as 'species recognition signals'. In order to function as 'species recognition signals', the patterns in these substances should be stable and the geographical variation in these patterns should be sufficiently low in order to avoid mistakes in species recognition. It could be shown recently, that this is the case (BERTSCH \& SCHweEr 2012). The compounds in male labial gland secretions can vary. Individual gland contents can change quantitatively and qualitatively (1) over the lifetime (see Ž́ÁČEK et al. 2009 and CoppéE et al. 2011 for $B$. terrestris), (2) during the day (secretions are used for scent marking in the morning, so glands may be depleted later on in the day; see Bergman 1997 for B. lapidarius) and (3) geographically, as shown for well-established subspecies of Bombus terrestris (CoppéE et al. 2008). In particular, the results of CoppéE et al. (2008) are astonishing, (1) because, contrary to information published so far (Bergström et al. 1968; Kullenberg et al. 1970; Bergström et al. 1981; Bergman 1997), in B.t.lusitanicus and B.t.terrestris 3,7,11-trimethyldodeca-6,10-dien-1-ol (2,3-dihydrofarnesol) is not the main component, and (2) because they found characteristic differences in gland secretion compositions between different subspecies. As variability in the pattern of substances in the labial gland secretions of male bumblebees is fundamentally important for their function as a 'species recognition signal', and as empirical science relies on the ability to independently verify results in different laboratories, we investigated the labial gland secretions of $B$. terrestris subspecies once more.

\section{Materials and Methods}

\section{Materials}

Table 1 shows the bumblebee samples used for the gas chromatography/mass spectrometry (GC/MS) investigations with their identification codes and the localities of their origins, with geographical coordinates. Old males were recognized by their frayed wings and were discarded. The wing borders of all of the males used for the labial gland preparations were smooth, indicative of active males. In males collected from the field (mostly in the afternoon, feeding on flowers) the glands were often more or less depleted; therefore, males should always be transported alive to the laboratory. We placed all of the males used for the investigation into small flight cages for at least 
$48 \mathrm{~h}$, where they were fed with honey solution. Then, they were frozen very early in the morning, which is a time of the day when the glands should be filled with the secretion, and prepared and analysed within a few days. In order to obtain older males of a known age, 7-day-old males were placed in large flight cages for a further 7 and 14 days, and then also frozen early in the morning. The cephalic part of the labial gland was dissected from the head while frozen and placed in a vial containing $0.2 \mathrm{ml}$ pentane. Because the aim of this investigation was to elucidate the chemical complexity and composition of male bumblebee labial glands from different geographical provenances rather than to study the variability in individual gland contents, we pooled the glands from five males into a single vial. This method allowed for the detection of even minor compounds present in the glands.

\section{Gas chromatography/mass spectrometry}

A Finnigan MAT TSQ700 gas chromatograph/tandem mass spectrometer was used. Gas chromatography was performed using a Hewlett Packard Ultra 1 column $(50 \mathrm{~m}, 0.2 \mathrm{~mm}$ internal diameter, $0.11 \mu \mathrm{m}$ film thickness) in a splitless mode, with helium as the carrier gas and an inlet pressure of $300 \mathrm{kPa}$. The split valve was opened after $1 \mathrm{~min}$. An initial temperature of $120^{\circ} \mathrm{C}$ was held for $1 \mathrm{~min}$, then increased at a rate of $8{ }^{\circ} \mathrm{C} / \mathrm{min}$ to $280^{\circ} \mathrm{C}$, followed by an increase at a rate of $3{ }^{\circ} \mathrm{C} / \mathrm{min}$ to $310^{\circ} \mathrm{C}$, and finally by $1{ }^{\circ} \mathrm{C} / \mathrm{min}$ to $320^{\circ} \mathrm{C}$. This final temperature was held for $10 \mathrm{~min}$. The mass spectrometry conditions were as follows: the interface temperature was $300{ }^{\circ} \mathrm{C}$, source temperature $130{ }^{\circ} \mathrm{C}$, electron energy $70 \mathrm{eV}$, emission current $0.2 \mathrm{~mA}$, and electron multiplier $1400 \mathrm{~V}$. Full-scan mass spectra were acquired over the range $\mathrm{m} / \mathrm{z} 45$ to 650 , with a scan cycle time of $0.5 \mathrm{~s}$. When the mass spectrometer was used in the positive ion chemical ionization (CI) mode, the ammonia CI gas pressure was $70 \mathrm{~Pa}$. The compounds were identified by comparing them with compounds in the NIST 2002 Library (National Institute of Standards and Technology, USA), along with retention times and molecular ions from the CI spectra. In order to determine the positions of double bonds, derivatization with dimethyl disulphide was used, as described by BUSER et al. (1983). Regression and statistics were calculated using the statistic toolbox of MATLAB ${ }^{\circledR}$.

\section{Results}

\section{The aging of males and the occurrence of esters}

In order to obtain older males, active males of about 7 days old were kept in a large flight cage for a further 7 and 14 days until their labial glands were prepared and investigated. Table 2 shows the percentage areas for the substances probably used in communication with the esters included (part 1) and with the esters excluded (part 2) for the males aged 14 and 21 days old. In three out of five 14-day-old males, 3,7,11-trimethyldodeca-6,10-dien-1-ol was the main component, whereas in four out of five 21-day-old males, 3,7,11-trimethyldodeca-(6E),10-dien-1-yl dodecanoate was the main component. Obviously, 3,7,11-trimethyldodeca-(6E),10-dien-1-ol could be present as free molecules or bound in $\mathrm{C}_{12}$-esters, and the ester part increased with age, where age means physiological age, mainly expressed as the duration of daily flight activity. The regression coefficient $\mathrm{r}^{2}=0.867$ predicted quite a good linear regression with $39 \%$ of the area for 3,7,11-trimethyldodeca-6,10-dien-1-ol in males without esters (Fig. 1), a value that was confirmed by the actual measurements (see Table 4). As the large amount of esters in the labial gland secretions made the representation and interpretation of the results quite difficult, most of the males used in this 


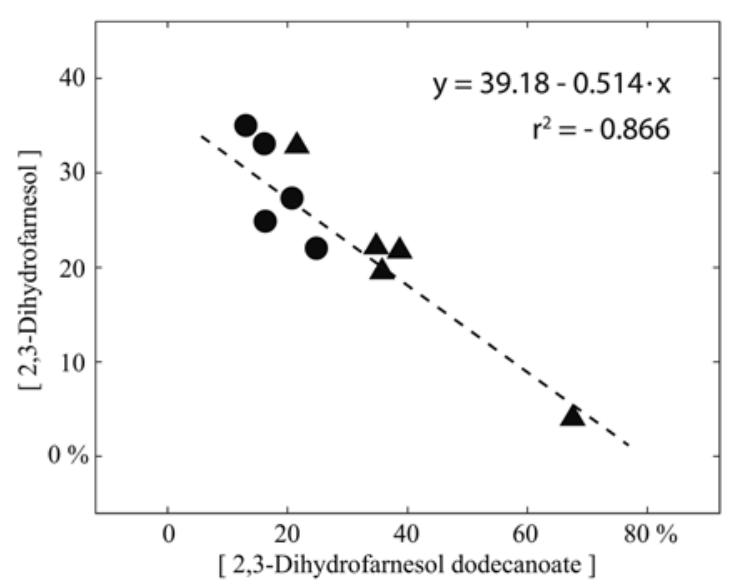

Fig. 1: Linear regression of the percentage of the total peak area of 2,3-dihydrofarnesol dodecanoate vs. 2,3-dihydrofarnesol for males of $B$. terrestris terrestris (Ter-07) aged 14 days $(\bullet)$ and 21 days $(\boldsymbol{\Delta})$ old; see Table 2 for details.

investigation were obtained from artificial colonies, and active males of about 7 days old (after emergence), with no or very low amounts of esters, were used for the investigation. Most of the males from the field collections (Lus-01, Ter-05, XaN-01, XAN-02, SAS-02 and SAS-02) did not contain esters either, or only contained small quantities. As we were interested in the amounts of substances used for communication and not in the composition of the labial gland secretion, we calculated the percentage area for all substances up to heptacosane $\left(\mathrm{C}_{27}\right.$ hydrocarbon), which excluded the esters from our analysis.

\section{Typical chromatograms of B. terrestris terrestris and B. terrestris xanthopus}

Typical chromatograms of male cephalic labial gland secretions of $B$. terrestris terrestris from Central Europe (Ter-07, a specimen with considerable amounts of esters) and B. terrestris xanthopus from Corsica (XAN-02, a specimen without any esters) are shown in Figure 2. The compounds identified are summarized in Table 3-1 (including specimen Ter-07) and Table 3-2 (including specimen XAN-02). The labial glands contained a mixture of acyclic sesqui- and diterpenes (alcohols, aldehydes, acetates) and various straight-chain fatty acid derivatives (alcohols, aldehydes, esters, and both saturated and unsaturated hydrocarbons with $\mathrm{C}_{21}-\mathrm{C}_{29}$ ).

In the labial glands of male $B$. terrestris terrestris (TER-07), the major compound was 3,7,11-trimethyldodeca-6,10-dien-1-ol (Fig. 2, with $45 \%$ of the total peak area, peak 8). In addition, LARGE AMOUNTs ( $>5 \%$ ) of ethyl dodecanoate (11\% of the total peak area, peak 3), 3,7,11,15-tetramethylhexadeca-6,10,14-trien-1-ol (12\% of the total peak area, peak 45) and icos-15-en-1-ol (6\% of the total peak area, peak 55) were detected. Furthermore, in MINOR AMOUNTs (1\%-5\%) a series of the alcohols hexadecane-1-ol (peak 20), octadeca-9,12,15-trien-1-ol (peak 34) and docos-15-en-1-ol (peak 62) was detected. Four more alcohols, tetradecan-1-ol (peak 7), octadeca-9,12-dien-1-ol (peak 33), icos-13-en-1-ol (peak 54) and docos-17-en-1-ol (peak 62), two

Fig. 2: Total ion chromatograms of pentane extracts from the cephalic labial gland secretions of Bombus terrestris terrestris (Ter-07, a specimen with esters, peak $74=3,7,11$-trimethyldodeca-6,10-dien-1-yl dodecanoate, peak $78=3,7,11$-trimethyldodeca-6,10-dien-1-yl tetradecenoate) and Bombus terrestris xanthopus (Xan-02, a specimen without esters). Numbers correspond to the numbers in the peak lists (Tables 3-1 \& 3-2). Some compounds listed in Tables 3-1 \& 3-2 were present in quantities that were too low to be visible in these chromatograms. 

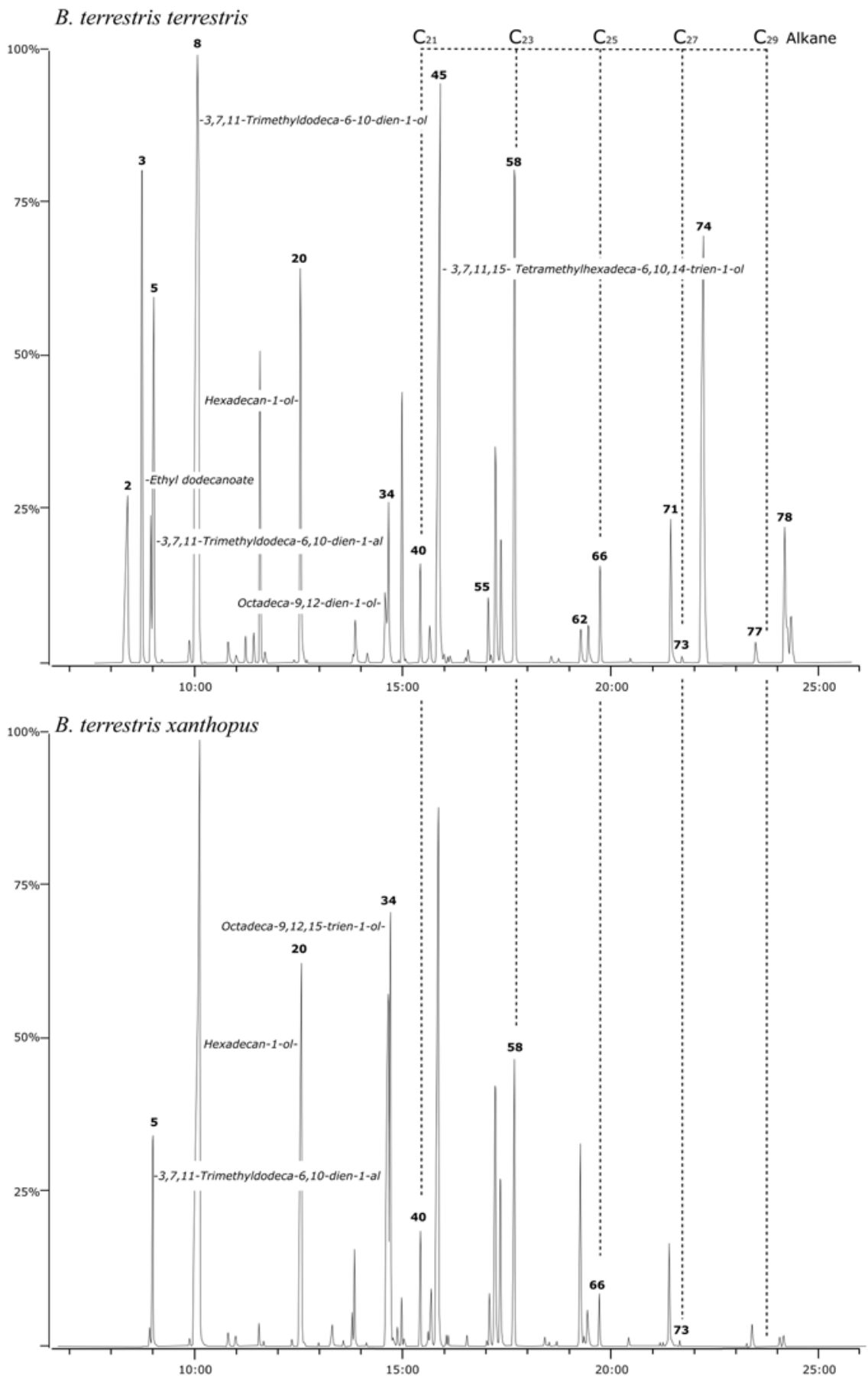

Fig. 2: Legends on p. 106 
aldehydes, tetradecanal (peak 4), and 3,7,11-trimethyldodeca-6,10-dienal (peak 5), and three acids, dodecanoic acid (peak 2), tetradec-9-enoic acid (peak 12) and octadec-11-enoic acid (peak 44) were also detected in SMALL AMOUNTS of between $0.2 \%-1 \%$.

In the labial glands of male B. terrestris xanthopus (XAN-02), the major compound was 3,7,11-trimethyldodeca-6,10-dien-1-ol (Fig. 2, with $50 \%$ of the total peak area, peak 8). In addition, LARGE AMOUNTS (> 5\%) of octadeca-9,12-dien-1-ol (7\% of the total peak area, peak 33), octadeca-9,12,15-trien-1-ol (10\% of the total peak area, peak 34), and 3,7,11,15-tetramethylhexadeca-6,10,14-trien-1-ol (9.5\% of the total peak area, peak 45) were detected. Furthermore, MINOR AMOUNTS (1\%-5\%) of 3,7,11-trimethyldodeca-6,10-dienal (1.3\%, peak 5), and a series of the alcohols hexadecane-1-ol (3.4\%, peak 20), icos-15-en1 -ol (4.2\%, peak 55) and docos-15-en-1-ol (1.2\%, peak 62) were detected. Three more alcohols, hexadec-11-en-1-ol (peak 19), octadec-13-en-1-ol (peak 35), icos-13-en-1-ol (peak 54) and docos-17-en-1-ol (peak 63), two aldehydes, octadeca-9,12,15-trienal (peak 29) and 3,7,11,15-tetramethylhexadeca-6,10,14-trienal (peak 37), and three acids, tetradec-9-enoic acid (peak 12), hexadec-9-enoic acid (peak 24) and octadecatrienoic acid (peak 42), were also detected in SMALL AMOUNTS of between $0.2 \%-1 \%$.

The labial gland secretions of the males B. t. xanthopus from Corsica and B. t. sassaricus from Sardinia differed from all of the other subspecies investigated in terms of the absence of dodecanoic acid and ethyl dodecanoate.

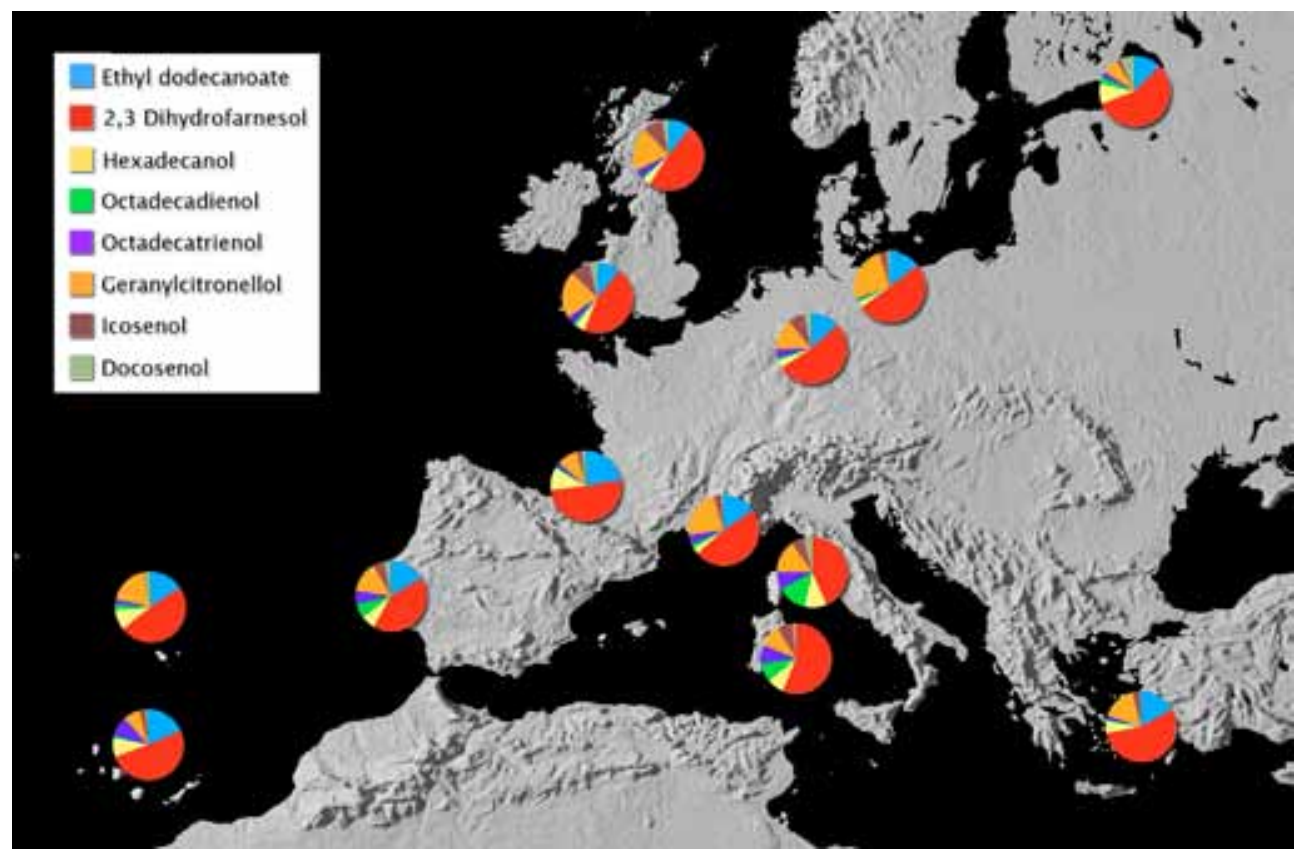

Fig. 3: Map with pie charts for the eight, probably 'active', compounds ('active' compounds $=100 \%$ ), illustrating the composition of labial gland secretions of $B$. terrestris.

\section{Geographical variation in gland contents}

The geographical variation in the pattern of compounds of male labial lands throughout the area of $B$. terrestris distribution was low (see Fig. 3). Naturally, variability was found in the amounts of the compounds, but this variability was not a geographical variation and was not connected with 
the subspecies. The variation in specimens from the islands (B. t. audax from the UK, B. t. maderensis from Madeira, B. t. canariensis from the Canary Islands, and B. t. dalmatinus from Samos) was within the levels of variation found for the specimens from the European continent (see Table 4). The variability in the amounts of compounds from single males of the same artificial colony was in the same order of magnitude as from males collected in the same geographical area (Ter-03 and Ter-04 from Hessen/Germany, or Ter-05, Ter-06 from Berlin/Germany, and Ter-07 from Brandenburg/Germany). Only males from the Mediterranean islands of Corsica and Sardinia differed since they were found to be completely devoid of dodecanoic acid and ethyl dodecanoate, whereas ethyl dodecanoate amounted to about $10 \%$ of total peak area in all of the other specimens.

\section{Discussion}

\section{Flight path activity and scent marking}

Flight path activity and scent marking has long been observed for many bumblebee species and male cephalic labial gland secretions have been investigated in great detail; however, the exact function of these secretions is still unknown. In earlier studies, SLaden (1912) stated that the male scent 'attracts not only males but the queens' and, following the first chemical investigations, Kullenberg et al. (1973) formulated the hypothesis that these compounds are sex pheromones that attract virgin females, a hypothesis described in more detail by Svensson (1980) and finally by Bergman (1997). Meanwhile, this hypothesis has been repeated so often that it is very often cited as fact (Hefetz 1998; Chalíková et al. 2004; Krieger et al. 2006; Coppée et al. 2008). Concerning B. terrestris, we know (1) the complete inventory of compounds in the cephalic labial glands of females (Hefetz et al. 1996; Krieger et al. 2006) and males (Bergman 1997; Coppée et al. 2008), (2) there have been a few dual-choice experiments where virgin queens were more attracted to chambers with male labial gland scents than to unscented chambers (BERGMAN 1997), and (3) electroantennogram investigations have shown that some of the compounds in male and female labial gland secretions elicit responses, i.e. there must be receptors for these compounds (Bergman 1997; Krieger et al. 2006; Coppée 2010). But it is also a fact that the attraction of females to male flight path activity or to scent-marked places is a rare event, for which we only have a few 'anecdotal reports' (Awram 1970; Free 1971; Svensson 1979), and attempts to experimentally investigate these matters have not produced conclusive results (FrEE 1971). Last, but not least, the flight path activity and scent marking of $B$. terrestris males are almost completely unknown, since the detailed descriptions of Frank (1941) refer to the flight path activities of B. hortorum (see HaAs 1949, p. 294), and only two studies reporting on the flight path activity of $B$. terrestris males have been casually undertaken (HAAs 1949, p. 294-295; Fussell \& CorbeT 1992). Though B. terrestris is very abundant in Germany and in late summer males are everywhere feeding at flowers, personal attempts to detect their flight path activity failed. After feeding the males leave the flowers in a very fast vertical flight and disappear high up, obviously their flight path activity is far away from the food sources and difficult to detect. A possible explanation could be that scent marking and flight path activity are not on top but within the dense vegetation cover, according to HAAS (1949) within the vegetation of a potato-field where the males scent mark more or less 'invisibly' $10-40 \mathrm{~cm}$ above ground. Goulson (2010) undertook a comprehensive survey and came to the conclusion that patrolling and scent marking is a 'poorly understood subject'. Further investigations are needed to understand the chemoecology of mating bumblebees and the function of male cephalic labial gland secretions. 


\section{The problem with ethyl esters}

One of the unsolved riddles in the analysis of male bumblebee labial glands, especially in $B$. terrestris, is the occurrence of a considerable amount of esters with a high molecular weight, substances that have a low volatility and which are unsuitable for communication. According to Francke et al. (1984), the esters may form a reservoir from which 'active' alcohols can be easily released by esterases. Available evidence suggests that this occurrence of esters is connected to the aging of males (Ž́́ČEK et al. 2009; CoppéE et al. 2011), a finding confirmed by our investigations. Therefore, it is essential to use fresh, active males in gland analyses and to use males with full glands by freezing them very early in the morning, a condition that can be best fulfilled by using males from artificial colonies. Careful inspection of the glands and the gland vesicles with a binocular microscope is also a good way of checking for fresh males with full gland vesicles. All of the specimens used in our analysis, including those collected from the field, were kept alive, observed in flight cages and immediately analysed after gland preparation. When this is not possible, specimens should be stored at $-25^{\circ} \mathrm{C}$ as whole animals without gland preparation, or prepared glands must be stored at $-80^{\circ} \mathrm{C}$, otherwise chemical reactions may change the substances in the prepared sceretions.

\section{Variability in gland contents}

As the results of Coppée et al. (2008), Lecoce (2009), Coppée (2010), and Coppée et al. (2011) are only given as median values without the original data it is difficult to 'explain' the significant differences between their results and ours, but the large differences between the minimum and maximum values for most of the substances indicate a large variability, the cause of which remains unclear. Perhaps some of these differences were caused by the analysis of single males, where some of the substances with very low peak areas might have been difficult to detect compared to our analysis on the combined secretions of five males. For B. t. dalmatinus, astonishingly large differences can be found between the values reported in the literature for gland contents (Coppée et al. 2008; Coppée et al. 2011; De Meulemeester et al. 2011), although no references were made to these differences (see Table 5). These discrepancies could have been due to differences in the treatment of males or gland extracts between being caught in the field and analysed by GC/MS, or they could have been due to the column length used. We found overlapping peaks for tetradecanal (retention time $(\mathrm{RT})=9: 04 \mathrm{~min}$ ) and 3,7,11-trimethyldodeca-6,10-dienal $(\mathrm{RT}=9: 07 \mathrm{~min})$, and octadeca-9,12-dien-1-ol $(\mathrm{RT}=15: 54 \mathrm{~min})$ and octadeca-9,12,15-trien-1-ol $(\mathrm{RT}=15: 57 \mathrm{~min})$, even with a $50 \mathrm{~m}$-long capillary column compared to the $30 \mathrm{~m}$-long column used by CoppéE et al. (2008). Furthermore, we used a shorter scan cycle time, of about 0.5 s, compared to CoppéE et al. (2008), CoppéE et al. (2011) and De Meulemeester et al. (2011), who all used a scan cycle time of $1 \mathrm{~s}$, which resulted in more non-separated peaks. Also, software quantification rather than manual quantification could result in a greater variability, as double peaks or peaks with shoulders could be integrated into one single peak. In such problematic cases, the data of GC with chemical ionization are of great help because overlapping substances can be separated by the differences in their molecular ions. We also believe that it is necessary to not only publish minimum, maximum and median values, but also the original data for each GC (at least as an appendix in a $\mathrm{PhD}$ thesis); only then can existing discrepancies be fully understood and perhaps even explained. 


\section{Geographical variability of a 'species recognition signal'}

The geographical variability of male labial gland secretions in bumblebees over large distances has not yet been investigated in detail. Comparisons have mainly been made within Europe and, with the exception of B. terrestris (CoppéE et al. 2008) and Bombus rupestris (UrbanovÁ et al. 2004) subspecies, the differences found between geographical provenances so far have been small. Coppée et al. (2008), LecocQ (2009) and Coppée (2010) reported several differences in the composition of labial gland secretions of $B$. terrestris subspecies. However, besides the complete absence of dodecanoic acid and ethyl dodecanoate in B. t.xanthopus and B. t. sassaricus, we could not detect any significant differences. None of the differences reported by CoppéE et al. (2008), Coppée (2010) and (LeCocQ) 2009 could be confirmed by our investigations.

Fresh males of B.t.lusitanicus (collected at the beginning of March in the present study) contained no esters at all, whereas 3,7,11-trimethyldodeca-6,10-dien-1-yl dodecanoate was the main component (median $=21.32 \%$ ) in males of B. t. lusitanicus investigated by CoppéE et al. (2008). In B. t. terrestris males collected from two different localities in southern France in the present study, the amount of esters was very low and 3,7,11-trimethyldodeca-6,10-dien-1-ol was the main component (median $=32.7 \%$ and $39.7 \%$ ), whereas in the B.t.terrestris males from southern France investigated by CoppéE et al. (2008), 3,7,11-trimethyldodeca-6,10-dien-1-yl dodecanoate $($ median $=18.29)$ was the main component. It was shown that the occurrence of esters is caused by aging of the males and therefore we concluded that some of the males investigated by CoppéE et al. (2008) might have been old males or, at the very least, their results were not typical for the subspecies B. t. lusitanicus and B. t. terrestris.

Specimens of the subspecies B. t. lusitanicus, B. t. terrestris, B. t. dalmatinus and B. t. sassaricus were investigated by Coppée et al. (2008) (Table 1, p. 2657) and B. t. xanthopus was investigated by Lecoce (2009) (Table 20, p. 64). The main differences reported by these authors were qualitative differences, i.e. the occurrence or the absence of some minor compounds. In B. t. dalmatinus, tetradecanal (median $=1.01 \%$ ) and 3,7,11-tetramethyldodeca-6,10-dienal (median $=1.87 \%$ ) were detected, although they were not present in B. t. terrestris, B. t. lusitanicus, B. t. sassaricus or B. t. xanthopus. Bombus terrestris ssp. sassaricus was distinguished by the presence of octadeca-9,12-dien-1-ol (median $=11.2 \%)$ and octadeca-9,12,15-trien-1-ol (median $=4.39 \%$ ), which were also detected in B.t.xanthopus, whereas in B.t. dalmatinus only octadeca-9,12-dien-1-ol was present (median $=0.81 \%$ ), and B. t. terrestris and B. t. lusitanicus were devoid of both substances. Some other differences could be quoted but none of these were confirmed by our investigation. Table 5 summarizes the results for B. t. dalmatinus by Coppée et al. (2008), Coppée et al. (2011) and De Meulemeester et al. (2011); all three investigations used specimens from commercial colonies in Rhodes (Rhodos). It is quite obvious that the absence of certain substances in the results of CoppéE et al. (2008) was not confirmed by the results of De Meulemeester et al. (2011). Furthermore, the specimens investigated by Coppée et al. (2008) and Coppée et al. (2011) were devoid of the alcohols tetradecan-1-ol, hexadecen-1-ol, octadecatrien-1-ol, icosen-1-ol and docosen-1-ol, whereas in the specimens investigated by De Meulemeester et al. (2011, a publication in which A. Coppée was a co-author) all of these alcohols were detected, quite in agreement with our results for B. t. dalmatinus from Samos (DAL-01). It is possible that treatment of these specimens with the criteria and methods used by CoppéE et al. (2008) would result in these B. t. dalmatinus specimens from the same provenance being assigned to different 'subspecies'. It is difficult to decide whether these 'differences' resulted from differences in the treatment of specimens prior to GC/MS analysis or from insufficiencies in the GC/MS methodology; however, in either case these 'differences' simply do not exist. 


\section{The subspecies concept in B. terrestris}

Infraspecific variation has always been of great interest in the description of bumblebees. At the beginning of the last century, each small aberration in colour was given a different name; in particular, Oskar Vogt and collaborators (mainly Edgar Krüger) invested a lot of effort investigating this phenomenon. KRÜGER $(1954,1956)$ described entire populations (which he called geographical races) of $B$. terrestris in great detail. The central theme of Krügers careful investigations in bumblebee colouration (called phenoanalytic studies) was the detailed study of clinal variation, for instance the gradual change of a narrow melanized collare of colouration type semipostcollaris (Krügers gradus II) into a broad yellow collare of colouration type latocollaris (Krügers gradus VIII) by the gradual increase in yellow hair. A good summary for the large variation in the colouration of the collare can be found in KRÜGER (1958, table at p. 305), where the first seven lines represent the variation in colouration of $B$. t. terrestris. Meanwhile, the local populations with different colourations were treated as subspecies; for example, RASMONT et al. (2008) provided a recent summary of the situation with coloured figures. But whereas KRÜGER $(1954,1956)$ put a lot of work into the details of colour variations within his local populations, RASMONT et al. (2008) implied that the subspecies were quite colour-stable.

The analysis of colour patterns is complicated by variability and convergence, which probably occur due to selection in favour of Müllerian mimicry. As long as the genetic basis of colouration is unknown, the basis of the subspecies concept in $B$. terrestris is problematic. An example from the North American bumblebees might provide an insight into this problem: the case of B. (Pyrobombus) edwardsii (the nominate form with a black pile on the second and third abdominal tergites) and B. (Pyrobombus) melanogypus (the nominate form with a reddish-orange pile on the second and third abdominal tergites). This colour difference is inherited through a simple, two-allele, single-locus genetic system in which red is dominant over black (OwEn \& Plowright 1980), and both taxa are conspecifics. Selection for mimetic resemblance favours the red morph in the north and the black morph in the south, with a cline predicted by mathematical models (OWEN 1986) and confirmed by genetic investigations (Owen et al. 2010) where a selective differential of $1 \%$ is sufficient to account for the transition observed. Another example of inheritance is the red legs of B. t. sassaricus. According to Velthuis \& VAN Doorn (2006; cited on p. 436 as Duchateau, unpublished), the prominent red colouration is also inherited through a two-allele single locus system in which black is dominant over red. Is a colour difference with such a simple genetic background sufficient to establish subspecies?

Some of the subspecies, such as B. t. canariensis, B. t. sassaricus and B. t. xanthopus, are so different in terms of colouration compared to $B$. t. terrestris that a subspecies status could be acceptable and, as they are island populations, a certain level of genetic isolation and difference can be expected. But other subspecies, such as B. t. calabricus and B. t. dalmatinus, are difficult to distinguish and as the variability of colouration within these subspecies is not mentioned at all by Rasmont et al. (2008) the issue of clinal variation immediately comes to mind. For B. t. lusitanicus and B. t. terrestris, we find the remark 'there may be an intergradation between ssp. terrestris and ssp. lusitanicus, in a cline extending from S. France to central Germany, the hybrid being the form ferrugineus Schmiedeknecht' (Rasmont et al. 2008 p. 245). This statement includes two interesting details, where a cline is interpreted as hybridization and the result is a form, a colour morph. Krüger mainly worked with museum material where, over the course of time, the colour may have changed, but in some cases he also investigated fresh material, for example, a population of 185 queens of B. t. terrestris collected from HamburgStadtpark (KRÜGER 1954, p. 282-284). The variation in colouration described for this local population (about $1.5 \mathrm{~km}^{2}$ ) is remarkable, and $3.8 \%$ of the females were reported to belong to 
the form ferrugineus Schmiedennecht. Detection of the 'hybrid' B. t. lusitanicus $\times$ B. t. terrestris as far north as Hamburg is quite improbable. And nearly $4 \%$ of the specimens from this local population belong to colouration type latocollaris (Krügers gradus VIII), specimens with a broad yellow collare, whereas according to figure 1 in RASMONT et al. (2008) a broad collare is restricted to the subspecies B. t. calabricus and B. t. dalmatinus.

Therefore, this raises many questions. Where are the geographical borders and/or the respective clines between $B$. t. terrestris and $B . t$. dalmatinus, especially as $B . t$. dalmatinus, according to RASMONT et al. (2008), is said to have also a distribution in northern Italy to south-eastern France? Even more interesting would be the cline from B.t. calabricus (southern Italy) to $B$. $t$. dalmatinus (northern Italy) because the differences in colouration between both subspecies seem to be negligible if one follows the figure and description given by Rasmont et al. (2008). Personal observations and collections of $B$. terrestris in central Italy did not really provide the impression of a different subspecies, as the collare and yellow band on the second tergite were more prominent, and perhaps broader, but this could easily be due to the effect of clinal variation. The same was found for specimens of B. terrestris from northern Greece and Crimea, where the difference in colouration was also found to be negligible and the establishment of a separate subspecies, instead of clinal variation, seems doubtful. The suspicion that, in many cases, specimens are just named by their geographical provenience and not by the typical colouration of their subspecies remains.

\section{Conclusions}

The results of our investigation into the compounds of male labial gland secretions did not deliver any tangible facts to justify the separation into the so-called subspecies of the European continent (B. t. lusitanicus, B. t. terrestris, B. t. calabricus and B. t. dalmatinus). Only the labial gland secretions of $B$. t. xanthopus and B.t. sassaricus were found to differ significantly from those of the continental specimens but, as they were quite similar to each other, doubt remains about their status as separate subspecies. These results are in complete agreement with an analysis of mitochondrial DNA (BERTSCH 2010) where no differences were found between mitochondrial DNA markers in so-called subspecies of the European continent (B.t. lusitanicus, B. t. terrestris, B. t. calabricus and B. t. dalmatinus). Of the island populations, B. t. canariensis, B. t. xanthopus (unpublished data, BerTsCH et al.) and B. t. sassaricus were essentially different to specimens from the continent, but again, $B$. t. sassaricus and $B$. t. xanthopus were very similar to each other in terms of mitochondrial DNA markers. The differences in male labial gland secretions, mitochondrial DNA markers and colouration were not consistent and a lot more work must be undertaken to investigate the genetics of colouration and the clinal variation of colouration between postulated subspecies.

\section{References}

Awram, W. J. 1970: Flight route behaviour of bumblebees. - PhD Thesis, Imperial College London, UK.

Bergman, P. 1997: Chemical communication in bumblebee premating behaviour. - PhD Thesis, Göteborg University, Sweden.

Bergström, G.; Kullenberg, B.; Ställberg-Stenhagen, S. \& Stenhagen, E. 1968: Studies on natural odoriferous compounds. II. Identification of a 2,3-dihydrofarnesol as the main component of the marking perfume of male bumble bees of the species B. terrestris L. - Arkiv för Chemie 28 (31): 453-469. 
Bergström, G.; Svensson, B. G.; Appelgren, M. \& Groth, I. 1981: Complexity of bumble bee marking pheromones: biochemical, ecological and systematical interpretations. - In: Howse, P. E. \& ClÉMENT, J. L. (eds.), Biosystematics of Social Insects. Academic Press, London, New York, Systematic Association Special Volume No. 19: 175-183.

BERTSCH, A. 2010: A phylogenetic framework for the bumblebee species of the subgenus Bombus sensu stricto based on mitochondrial DNA markers, with a short description of the neglected taxon B. minshanicola Bischoff, 1936 n. status. - Beiträge Entomologie 60: 471-487.

Bertsch, A. \& Schweer, H. 2012: Male labial gland secretions as species recognition signals in species of Bombus. - Biochem. Systematics \& Ecol. 40: 103-111.

Buser, H. R.; Arn, H.; Guerin, P. \& Rauscher, S. 1983: Determination of double bond positions in mono-unsaturated acetates by mass spectrometry of dimethyl disulfide adducts. - Analytical Chemistry 55: 818-822.

Chalíková, L.; Hovorka, O.; Ptácek, V. \& Valterová, I. 2004: Exocrine gland Secretions of virgin queens of five bumblebee species (Hymenoptera: Apidae, Bombini). - Zeitschrift für Naturforschung 59c: 582-589.

CoppéE, A. 2010: Bombus terrestris (L. 1758): A complex species or a species complex? - PhD Thesis, University of Mons-Hainaut, Belgique.

Coppée, A.; Terzo, M.; Valterová, I. \& Rasmont P. 2008: Intraspecific variation of the cephalic labial gland secretions in Bombus terrestris (Hymenoptera: Apidae). - Chemistry and Biodiversity 5: 2654-2661.

Coppée, A.; Mathy, T.; Cammaerts, M. C.; Verheggen F.; Terzo, M.; Iserbyt, St.; Valterová, I. \& Rasmont, P. 2011: Age-dependant attractivity of males' sexual pheromones in Bombus terrestris (L.), (Hymenoptera, Apidae). - Chemoecology 21: 75-82.

Francke, W.; Schröder, W.; Bergström, G. \& Tengö, J. 1984: Esters in volatile secretions of bees. Nova Acta Regiae Societatis Scientiarum Upsaliensis V: C, 3: 127-136.

Frank, A. 1941: Eigenartige Flugbahnen bei Hummelmännchen. - Zeitschrift Morphologie Ökologie der Tiere 28: 467-484.

FreE, J. B. 1971: Stimuli eliciting mating behaviour of bumblebee (Bombus pratorum L.) males. - Behaviour 40: 55-61.

Fussell, M. \& Corbet, S. A. 1992: Observations on the patrolling behaviour of male bumblebees (Hymenoptera). - Entomologist's Monthly 29: 229-235.

Goulson, D. 2010: Bumblebees - behaviour, ecology and conservation. - Oxford University Press, Oxford, second edition.

HaAs, A. 1949: Arttypische Flugbahnen von Hummelmännchen. - Zeitschrift vergleichende Physiologie 31: 281-307.

Hefetz, A. 1998: Exocrine glands and their products in Non-Apis Bees: Chemical, Functional and Evolutionary perspectives, pp. 236-256. - In: VanderMeer, R. K.; Breed, M. D.; Winston M. L. \& Espelie, K. E. (eds.) Pheromone communication in social insects. Westview Press, Boulder, Colorado.

Hefetz, A.; Taghizadeh, T. \& Francke, W. 1996: The exocrinology of the queen bumble bee Bombus terrestris (Hymenoptera: Apidae, Bombini). - Zeitschrift Naturforschung 51c: 409-422.

Krieger, M.; Duchateau, M. J.; van Doorn, A.; Ibarra, F.; Francke, W. \& Ayasse, M. 2006: Identification of Queen sexpheromone components of the bumblebee Bombus terrestris. - Journal of Chemical Ecology 32: 453-471.

KRÜGER, E. 1954: Phaenoanalytische Studien an einigen Arten der Untergattung Terrestribombus O. Vogt (Hymenoptera, Bombidae). II. Teil. - Tijdschrift voor Entomologie 97: 263-298.

KRÜGER, E. 1956: Phaenoanalytische Studien an einigen Arten der Untergattung Terrestribombus O. Vogt (Hymenoptera, Bombidae). II. Teil. - Tijdschrift voor Entomologie 99: 75-105.

Kullenberg, B.; Bergström, G. \& Ställberg-Stenhagen, S. 1970: Volatile components of the cephalic marking secretions of male bumble bees. - Acta Chemica Scandinavica 24: 1481-1483. 
Kullenberg, B.; Bergström, G.; Bringer, B.; Carlberg, B. \& Ceederberg, B. 1973: Observations on Scent marking by Bombus Latr. and Psithyrus Lep. Males (Hymenoptera, Apidae) and localization of site of production of the secretion. - Zoon, Supplement, Uppsala 1: 23-30.

Lecoce, Th. 2009: Génetique et phéromones sexuelles des bourdons de la Corse. - Mémoire de Master en Biologie des organismes et écologies, Université de Mons-Hainaut, Belgique.

De Meulemeester, T.; Gerbaux, P.; Boulvin, M.; Coppée, A. \& Rasmont, P. 2011: A simplified protocol for bumble bee species identification by cephalic secretion analysis. - Insectes Sociaux 58: 227-236.

Owen, R. E. 1986: Gene frequency clines at X-linked or haplodiploid loci. - Heredity 57: 209-219.

Owen, R. E. \& Plowright, R. C. 1980: Abdominal pile color dimorphism in the bumble bee, Bombus melanopygus. - The Journal of Heredity 71: 241-247.

Owen, R. E.; Whidden, T. L. \& Plowright, R. C. 2010: Genetic and morphometric evidence for the conspecific status of the bees, Bombus melanopygus and B. edwardsii. - Journal of Insect Science 10 (109): 1-18.

Rasmont, P.; Coppée, A.; Michez, D. \& De Meulemeester, Th. 2008: An overview of the Bombus terrestris (L. 1758) subspecies (Hymenoptera, Apidae). - Annales de la Societe Entomologique de France 44: 243-250.

Sladen, F. W. L. 1912: The Humble-bee, its life-history and how to domesticate it. - Macmillan \& Co., London. - Reprint Logaston Press 1989.

Svensson, B. G. 1979: Pyrobombus lapponicus Auct., in Europe recognized as two species: P. lapponicus (FABRICIs, 1793) and P. monticola (SмITH, 1849) (Hymenoptera: Apoidea: Bombinae). - Entomologica Scandinanvica 10: 275-296.

Svensson, B. G. 1980: Species-isolating mechanisms in male bumble bees (Hymenoptera, Apidae). - PhD Thesis, University of Uppsala, Sweden.

Urbanová, K.; Halik, J.; Hovorka, O.; Kindl, J. \& Valterová, I. 2004: Marking pheromones of the cuckoo bumblebee males (Hymenoptera, Apoidea, Bombus Latreille): Composition of labial gland secretions of six species found in the Czech Republic. - Biochemical Systematics and Ecology 32: 1025-1045.

Valterová, I. \& Urbanová, K. 1997: Chemické signály čmeláků [Chemical signals of bumble bees]. Chemické Listy 91: 846-857 (in Czech).

Velthuis, H. H. W. \& van Doorn, A. 2006: A century of advances in bumblebee domestication and the economic and environmental aspects of its commercialization for pollination. - Apidologie 37: 421-451.

Žáčé, P.; Kalinová, B.; Šobotník, J.; Hovorka, O.; Ptáček, V.; Coppée, A.; Verheggen, F. \& VAlterová, I. 2009: Comparison of age-dependent quantitative changes in the male labial gland secretions of B. terrestris and B. lucorum. - Journal Chemical Ecology 35: 698-705.

Author's addresses:

Prof. Dr. Andreas Bertsch

Department of Biology

Philipps-University Marburg

Karl-von-Frisch-Straße

35032 Marburg, Germany

E-mail:bertsch@staff.uni-marburg.de
Subject editor:

Prof. Dr. K. DetTner
Dr. Horst SChWeer

Department of Pediatrics

Philipps-University Marburg

Baldingerstraße

35043 Marburg, Germany

E-mail: schweer@med.uni-marburg.de 


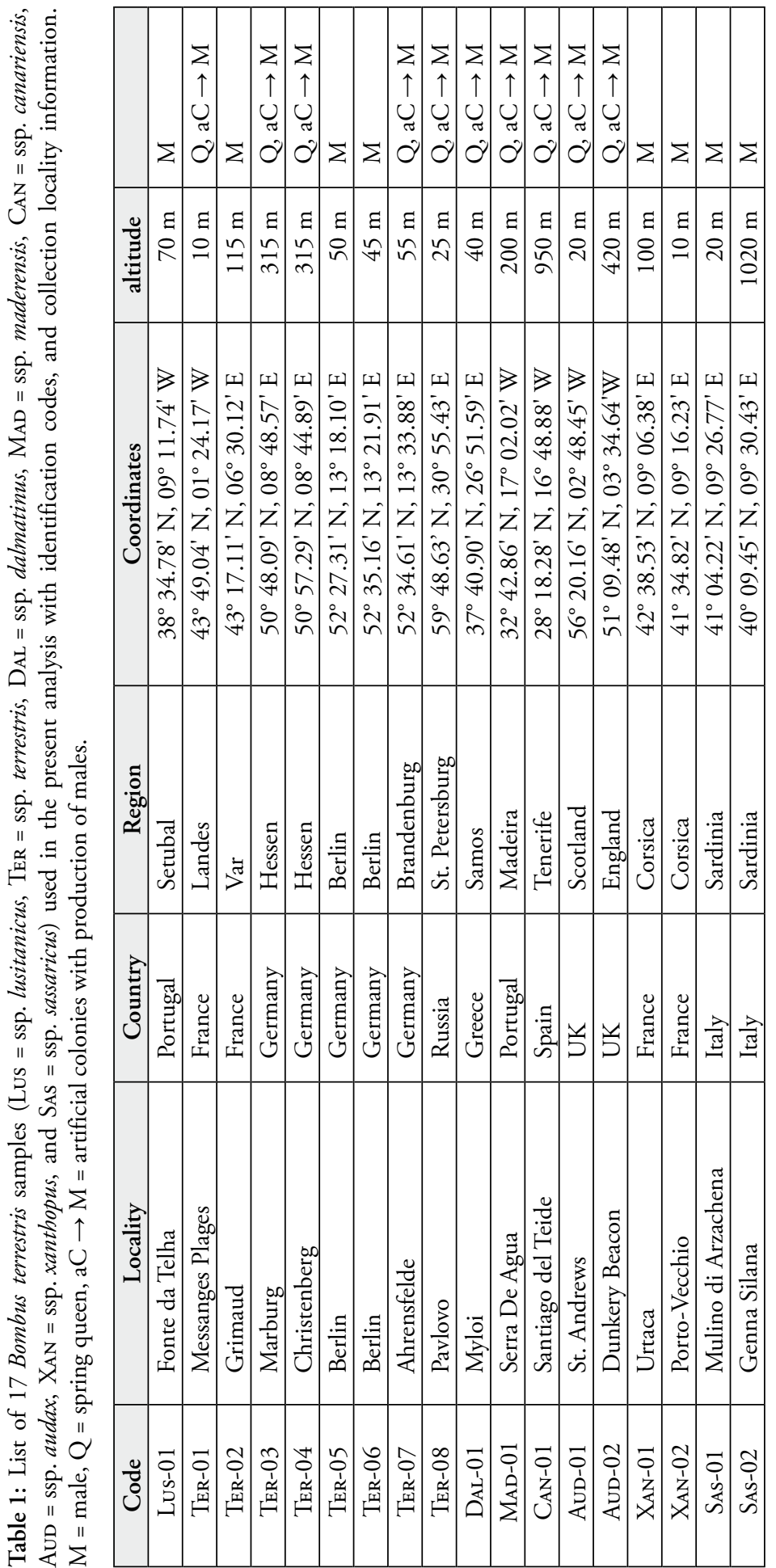




\begin{tabular}{|c|c|c|c|c|c|c|c|c|c|c|c|c|c|c|c|c|c|c|c|c|c|c|c|}
\hline in & $10^{\circ}$ & & $\overrightarrow{\hat{0}}$ & $\begin{array}{l}\varrho \\
\triangleq \\
\vec{\sim}\end{array}$ & $\hat{\sigma}$ & $\begin{array}{l}\vec{F} \\
0 \\
0\end{array}$ & $\mid \begin{array}{c}\infty \\
+ \\
0 \\
0\end{array}$ & 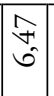 & $\begin{array}{l}\stackrel{F}{\Rightarrow} \\
\rightarrow\end{array}$ & $\begin{array}{l}0 \\
0 \\
0\end{array}$ & $\begin{array}{l}n \\
\hat{n} \\
m\end{array}$ & 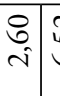 & 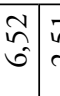 & $\begin{array}{l}\vec{n} \\
\hat{\imath}\end{array}$ & & $\hat{n}$ & 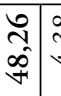 & 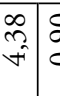 & 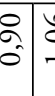 & $\stackrel{0}{\circ}$ & 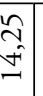 & $\begin{array}{l}\widehat{\grave{n}} \\
\hat{n}\end{array}$ & $\begin{array}{l}0 \\
0 \\
0\end{array}$ \\
\hline$\checkmark$ & $+10^{\circ}$ & & \begin{tabular}{c}
$\tilde{N}$ \\
\multirow{+}{*}{}
\end{tabular} & 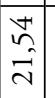 & $\tilde{c}$ & $\begin{array}{l}0 \\
\vdots \\
0\end{array}$ & $\mid \begin{array}{l}0 \\
0 \\
0\end{array}$ & $\begin{array}{l}\vec{\forall} \\
\stackrel{0}{*}\end{array}$ & $\stackrel{\overbrace{}}{=}$ & $\begin{array}{l}8 \\
0 \\
0\end{array}$ & $\begin{array}{l}2 \\
\hat{0} \\
\infty \\
m\end{array}$ & $\underset{\forall}{\hat{*}}$ & 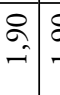 & $\stackrel{2}{\curvearrowright}$ & & $\begin{array}{l}\tilde{\sigma} \\
\sigma \\
\sigma\end{array}$ & $\begin{array}{c}0 \\
\delta \\
n \\
f\end{array}$ & $\approx$ & $=$ & $\begin{array}{l}\varrho \\
\sigma_{0}\end{array}$ & \begin{tabular}{l}
$\infty$ \\
\multirow{t}{n}{} \\
\end{tabular} & $\begin{array}{l}\hat{N} \\
\hat{i}\end{array}$ & $\begin{array}{l}* \\
0 \\
0\end{array}$ \\
\hline $\begin{array}{l}\frac{\pi}{0} \\
\vec{\tau} \\
\text { 品 }\end{array}$ & $50^{\circ}$ & & \begin{tabular}{|l|} 
\\
$\tilde{\sigma}$ \\
0
\end{tabular} & $\begin{array}{l}\tilde{\hat{~}} \\
\hat{\tilde{n}}\end{array}$ & $\begin{array}{l}0 \\
\hat{0} \\
0\end{array}$ & $\begin{array}{l}n \\
0 \\
0\end{array}$ & $\begin{array}{l}n \\
0 \\
0\end{array}$ & $\begin{array}{l}\infty \\
\infty \\
i\end{array}$ & $\stackrel{8}{\circ}$ & $\begin{array}{l}\tau \\
0 \\
0\end{array}$ & $\begin{array}{l}\infty \\
\stackrel{\sim}{\sim}\end{array}$ & $\begin{array}{l}F \\
\sim \\
n\end{array}$ & 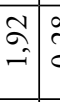 & 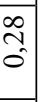 & & $\begin{array}{l}\sqrt{0} \\
6 \\
- \\
-1\end{array}$ & \begin{tabular}{l|l}
0 & 7 \\
0 & 7 \\
0 & 7
\end{tabular} & \begin{tabular}{l|l} 
& $=$ \\
$\approx$ &
\end{tabular} & $\begin{array}{l}\text { ָે } \\
\text { o }\end{array}$ & 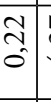 & 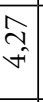 & ્ְટ & 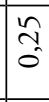 \\
\hline 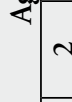 & $v \mid \partial^{\circ}$ & & 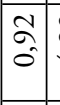 & \begin{tabular}{l}
$\tilde{\sim}$ \\
\multirow{f}{*}{}
\end{tabular} & $\mid \begin{array}{l}\infty \\
0 \\
0 \\
0\end{array}$ & $\begin{array}{l}\overrightarrow{0} \\
0\end{array}$ & $\left|\begin{array}{l}1 \\
\delta \\
0 \\
0\end{array}\right|$ & \begin{tabular}{l}
0 \\
\hdashline \\
-1
\end{tabular} & $\begin{array}{l}0 \\
0 \\
0\end{array}$ & $\begin{array}{l}8 \\
\vdots \\
0\end{array}$ & $\begin{array}{l}\stackrel{\infty}{+} \\
\hat{\sigma} \\
\hat{\sigma}\end{array}$ & $\begin{array}{c}\underset{f}{\sim} \\
\stackrel{i}{c}\end{array}$ & 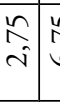 & $\overbrace{0}^{n}$ & & \begin{tabular}{l}
$\infty$ \\
\multirow{\sigma}{0}{}
\end{tabular} & $\begin{array}{l}m \\
m \\
m\end{array}$ & 气̂. & $\begin{array}{l}+ \\
\text { tr } \\
0\end{array}$ & $\begin{array}{l}m \\
\tilde{0} \\
\tilde{0}\end{array}$ & $\curvearrowright$ & $\begin{array}{l}0 \\
\vdots \\
0 \\
0\end{array}$ & $\begin{array}{l}8 \\
0 \\
0\end{array}$ \\
\hline- & $-10^{\circ}$ & & $\begin{array}{l}2 \\
\hat{n}\end{array}$ & $\begin{array}{l}0 \\
n \\
0 \\
i\end{array}$ & 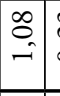 & $\begin{array}{c}\tilde{n} \\
\tilde{o}\end{array}$ & $\begin{array}{l}\infty \\
0 \\
0 \\
0\end{array}$ & $\overrightarrow{\widehat{N}}$ & $\approx$ & $\begin{array}{l}\overrightarrow{0} \\
0 \\
0\end{array}$ & \begin{tabular}{l}
\multirow{2}{n}{} \\
$n$ \\
$n$
\end{tabular} & 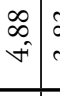 & \begin{tabular}{l|l}
$\infty$ & \\
$\infty$ & \\
$m$ &
\end{tabular} & $\stackrel{\vec{m}}{\hat{n}}$ & & \begin{tabular}{l}
\multirow{2}{*}{} \\
$\infty$
\end{tabular} & $\begin{array}{c}\text { त్t } \\
\text { țt }\end{array}$ & 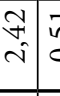 & $\tilde{\tilde{\sigma}}$ & $\begin{array}{c}\vec{F} \\
0 \\
0\end{array}$ & $\begin{array}{l}0 \\
0 \\
0 \\
0\end{array}$ & 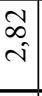 & $\begin{array}{l}0 \\
0 \\
0\end{array}$ \\
\hline n & $10^{\circ}$ & & $\hat{\tilde{\alpha}}$ & $\begin{array}{l}\hat{\sigma} \\
\vec{\sim}\end{array}$ & $\tilde{N}$ & $\begin{array}{l}\hat{\sigma} \\
0\end{array}$ & $\vec{n}$ & $\begin{array}{l}\hat{\hat{n}} \\
\stackrel{n}{n}\end{array}$ & $\stackrel{\curvearrowright}{-}$ & 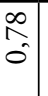 & \begin{tabular}{l}
$\mathfrak{n}$ \\
\multirow{d}{*}{}
\end{tabular} & $\begin{array}{c}0 \\
\vdots \\
\dot{m}\end{array}$ & $\begin{array}{ll}\stackrel{\infty}{n} \\
\end{array}$ & $\underset{\overbrace{}}{\stackrel{0}{-}}$ & & $\begin{array}{l}\infty \\
\stackrel{\nabla}{\sigma}\end{array}$ & 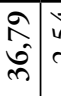 & 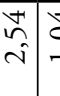 & $\stackrel{+}{0}$ & $\begin{array}{l}\tilde{n} \\
\tilde{0}\end{array}$ & 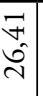 & $\begin{array}{l}\vec{n} \\
m\end{array}$ & $\vec{n}$ \\
\hline$\checkmark$ & $+10^{\circ}$ & & $\begin{array}{l}\hat{\sigma} \\
\infty\end{array}$ & $\mid$\begin{tabular}{l}
$\mathbb{N}$ \\
\multirow{n}{*}{}
\end{tabular} & \begin{tabular}{l}
\multirow{f}{*}{} \\
$\mathrm{v}$
\end{tabular} & సે & $\begin{array}{l}\infty \\
\mathfrak{n} \\
0\end{array}$ & $\mid \begin{array}{c}\hat{y} \\
\stackrel{\prime}{z}\end{array}$ & $\begin{array}{c}\overrightarrow{0} \\
\dot{m}\end{array}$ & $\vec{\beth}$ & $\begin{array}{l}m \\
m \\
m\end{array}$ & $\begin{array}{l}\hat{\kappa} \\
\hat{v}\end{array}$ & 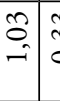 & $\stackrel{m}{\tilde{0}}$ & & $\begin{array}{l}\hat{\imath} \\
=\end{array}$ & 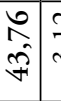 & \begin{tabular}{c|c}
$\vec{m}$ & \\
$\dot{m}$ &
\end{tabular} & $\begin{array}{l}\stackrel{\sigma}{t} \\
0\end{array}$ & 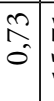 & $\begin{array}{l}\mathbb{n} \\
\stackrel{n}{n}\end{array}$ & $\begin{array}{l}\infty \\
\infty \\
n\end{array}$ & $\stackrel{n}{n}$ \\
\hline 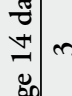 & $\therefore 0^{\circ}$ & & $\begin{array}{l}\text { I } \\
\text { i }\end{array}$ & $\begin{array}{l}\stackrel{2}{a} \\
\stackrel{-}{0}\end{array}$ & $\begin{array}{l}2 \\
\infty \\
0\end{array}$ & $\begin{array}{l}n \\
0 \\
0\end{array}$ & 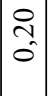 & $\mid \begin{array}{c}\infty \\
\dddot{2} \\
\infty\end{array}$ & $\begin{array}{c}1 \\
\infty \\
0\end{array}$ & 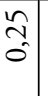 & $\begin{array}{c}\hat{\tilde{z}} \\
\hat{f}\end{array}$ & \begin{tabular}{l|l}
$\infty$ & $\delta$ \\
- &
\end{tabular} & 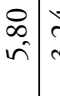 & $\stackrel{\mathbb{N}}{\stackrel{n}{*}}$ & & $\frac{m}{\sigma}$ & $\begin{array}{l}+ \\
\infty \\
\approx \\
f\end{array}$ & 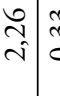 & $\begin{array}{l}\tilde{2} \\
\hat{0}\end{array}$ & $\begin{array}{l}\vec{n} \\
\tilde{0}\end{array}$ & $\begin{array}{l}\stackrel{n}{\hat{\lambda}} \\
\vec{v}\end{array}$ & $\begin{array}{l}\hat{0} \\
\hat{\imath}\end{array}$ & \begin{tabular}{l}
\multirow{6}{*}{} \\
0 \\
0
\end{tabular} \\
\hline$<$ & $v \mid \partial^{\circ}$ & & $\mid \begin{array}{l}0 \\
\dddot{n} \\
0 \\
\sim\end{array}$ & $\begin{array}{l}\hat{\approx} \\
\hat{n}\end{array}$ & $\stackrel{0}{\cong}$ & $\begin{array}{l}-\infty \\
\infty \\
0\end{array}$ & $\begin{array}{l}n \\
6 \\
0\end{array}$ & $\mid \begin{array}{l}\infty \\
\underset{-1}{0}\end{array}$ & $\stackrel{\curvearrowright}{\approx}$ & $\begin{array}{c}2 \\
\hat{\sigma}\end{array}$ & $\begin{array}{l}0 \\
\sim \\
\sim \\
\sim\end{array}$ & $\begin{array}{ll}\hat{\sim} \\
\hat{n}\end{array}$ & $\begin{array}{l}\stackrel{=}{=} \\
=\end{array}$ & $\begin{array}{l}\hat{\sigma} \\
0\end{array}$ & & $\begin{array}{l}2 \\
\infty \\
\hat{n}\end{array}$ & 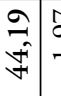 & $\hat{\approx}$ & $\hat{\mathrm{O}}$ & $\begin{array}{l}0 \\
\infty \\
0 \\
0\end{array}$ & $\begin{array}{l}\stackrel{\sigma}{\sigma} \\
\stackrel{\Omega}{2}\end{array}$ & $\begin{array}{l}\text { तु } \\
i \\
\hat{i}\end{array}$ & $\vec{\sim}$ \\
\hline- & $-10^{\circ}$ & & $\begin{array}{l}8 \\
0 \\
0 \\
i\end{array}$ & 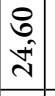 & $\vec{\sim}$ & $\hat{n}$ & $\begin{array}{l}0 \\
i \\
0\end{array}$ & $\mid \begin{array}{c}\hat{\sim} \\
\stackrel{n}{n}\end{array}$ & $\stackrel{\mathfrak{O}}{-}$ & $\begin{array}{l}\hat{0} \\
\hat{0}\end{array}$ & $\begin{array}{l}\hat{\imath} \\
\hat{\sigma}\end{array}$ & Әे & 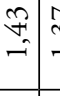 & $\hat{\approx}$ & & 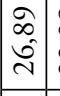 & 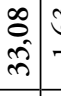 & 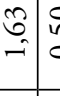 & $\begin{array}{l}0 \\
\hat{0} \\
0\end{array}$ & $\begin{array}{l}n \\
\tilde{z} \\
o\end{array}$ & $\begin{array}{l}\hat{\sigma} \\
\text { : } \\
\text { ते }\end{array}$ & & $\stackrel{2}{0}$ \\
\hline & $\stackrel{N}{\Xi}$ & & 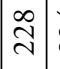 & $\stackrel{\mathbb{N}}{\sim}$ & $\underset{\sim}{\stackrel{\sim}{\sim}}$ & 뉴 & ث্ & নิ & ঐे & $\underset{\sim}{\mathbb{n}}$ & ๖े & $\widetilde{\widetilde{f}}$ & $\underset{7}{\mathbb{T}}$ & $\underset{\forall}{\stackrel{+}{*}}$ & & 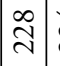 & $\underset{\sim}{\mathbb{N}}$ & $\underset{\Im}{\stackrel{\sim}{\sim}}$ & 뉴 & : & ๙ิ & 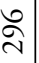 & $\underset{\sim}{\mathbb{N}}$ \\
\hline & 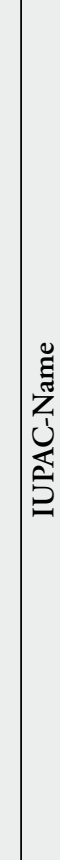 & 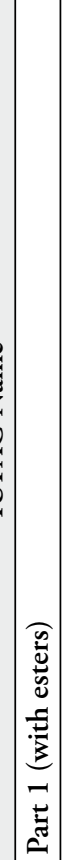 & 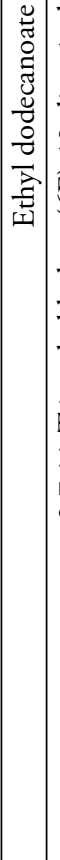 & 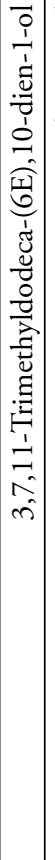 & 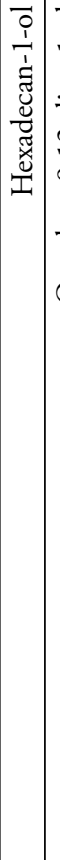 & 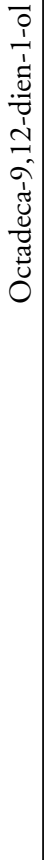 & 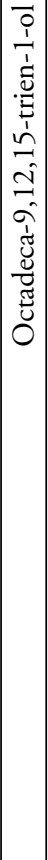 & 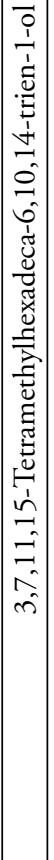 & 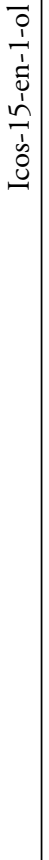 & 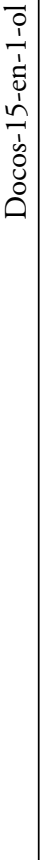 & 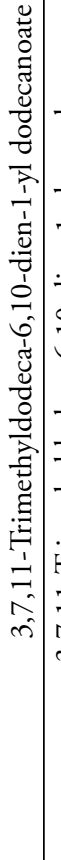 & 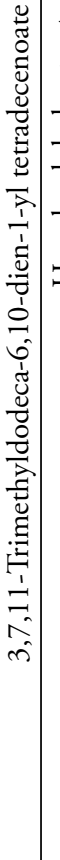 & 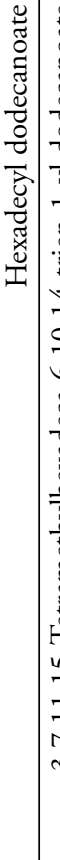 & 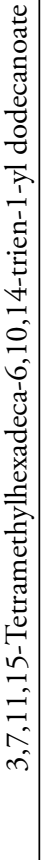 & 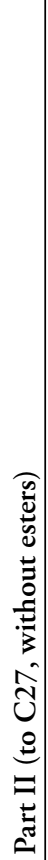 & 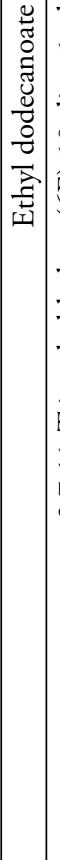 & 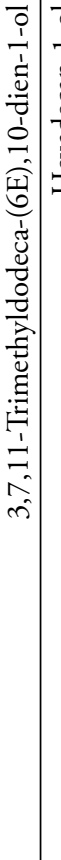 & 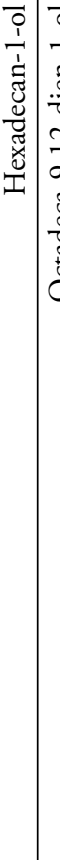 & 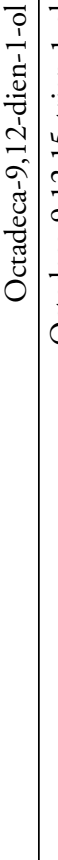 & 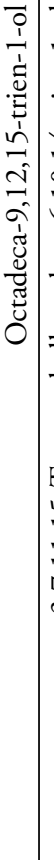 & 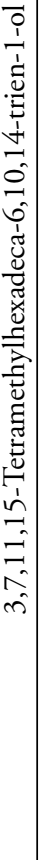 & 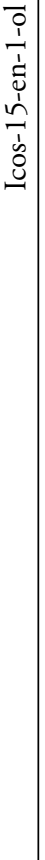 & 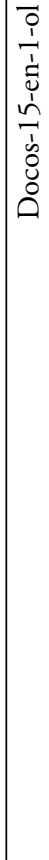 \\
\hline
\end{tabular}




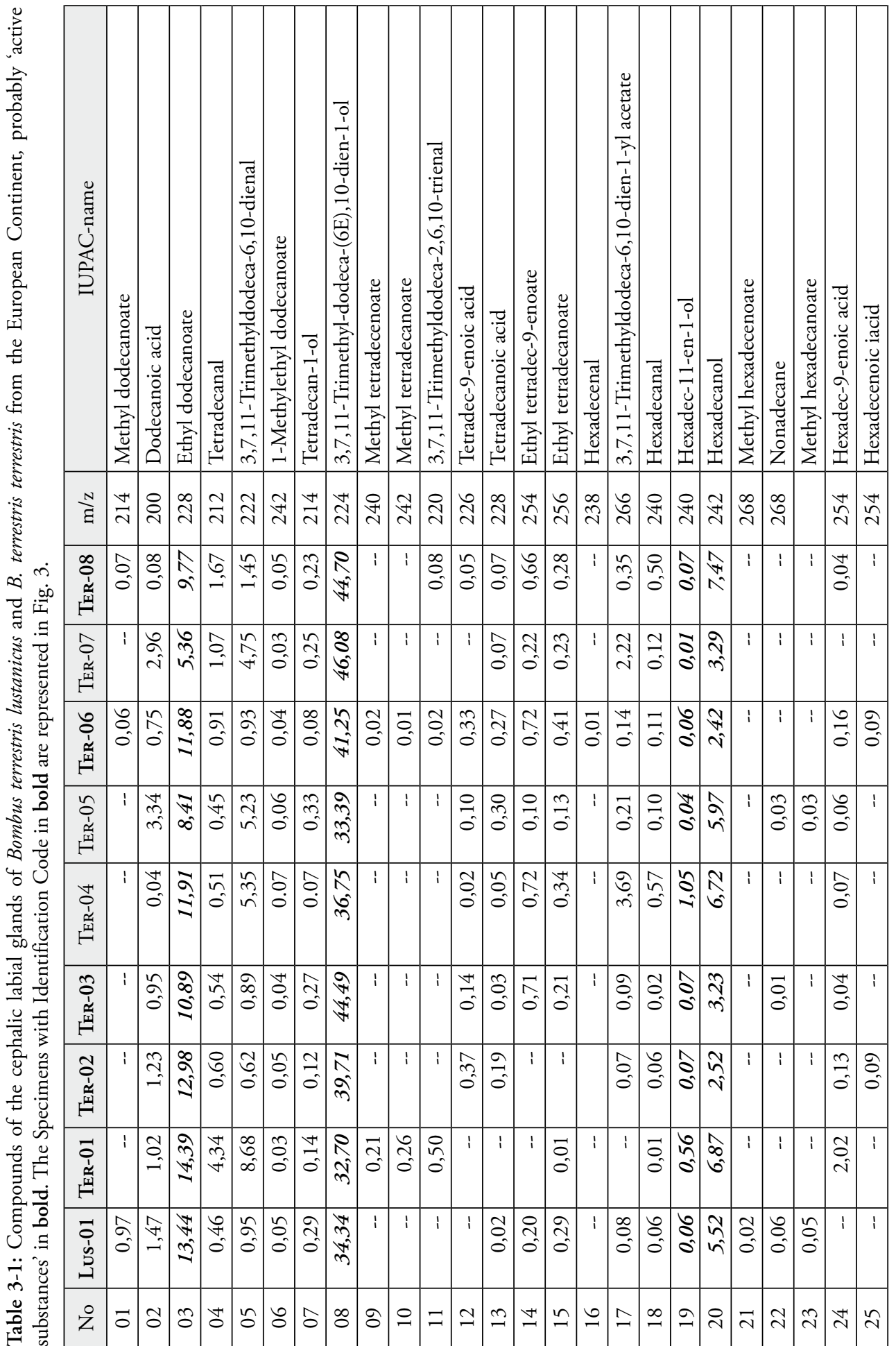




\begin{tabular}{|c|c|c|c|c|c|c|c|c|c|c|c|c|c|c|c|c|c|c|c|c|c|c|c|c|c|c|}
\hline 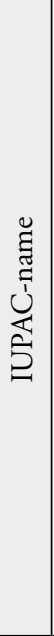 & 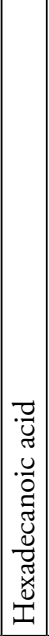 & 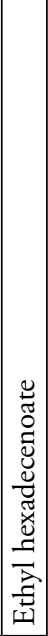 & 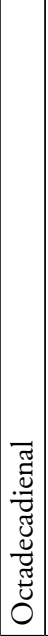 & 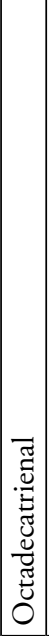 & 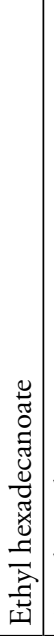 & 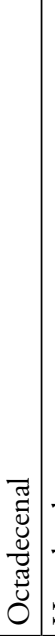 & 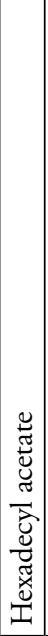 & 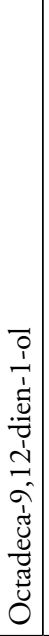 & 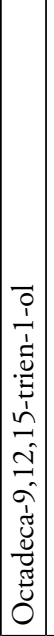 & 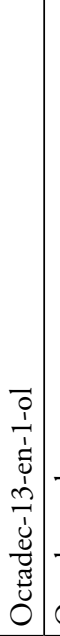 & 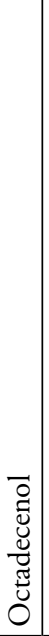 & 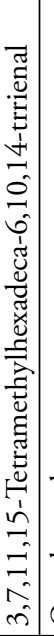 & 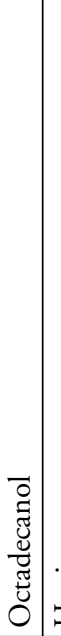 & 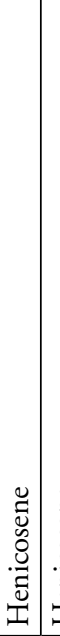 & 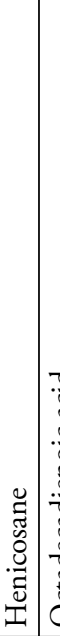 & 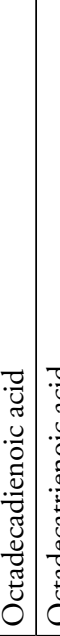 & 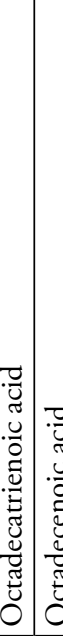 & 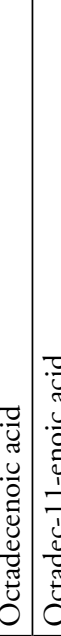 & 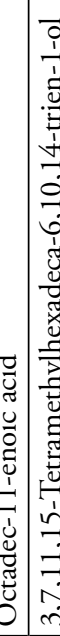 & 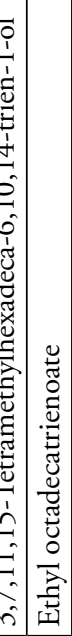 & 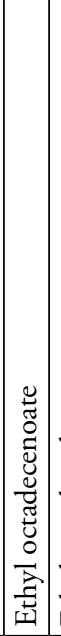 & 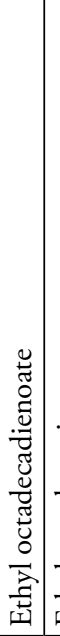 & 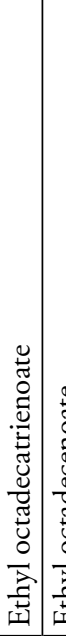 & 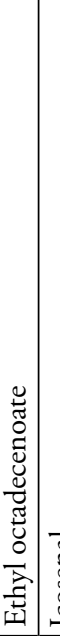 & 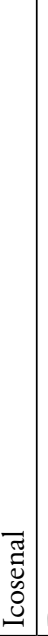 & \\
\hline है & 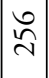 & $\begin{array}{c}\sim \\
\infty \\
\sim\end{array}$ & $\begin{array}{l}\stackrel{*}{*} \\
\sim\end{array}$ & $\mid \begin{array}{c}\mathcal{O} \\
\text { N }\end{array}$ & $\begin{array}{l}\stackrel{+}{*} \\
\sim \\
\sim\end{array}$ & 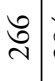 & $\begin{array}{l}+* \\
\stackrel{\infty}{*}\end{array}$ & : & 式 & $\begin{array}{l}\infty \\
\dot{D} \\
\sim\end{array}$ & 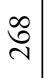 & 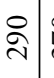 & $\stackrel{\curvearrowright}{\curvearrowright}$ & $\stackrel{\varpi}{\overparen{\nabla}}$ & 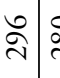 & \begin{tabular}{l|l}
8 & 0 \\
$\infty$ & 1 \\
&
\end{tabular} & 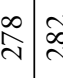 & \begin{tabular}{l|l}
$\infty$ & $\infty$ \\
$\sim$ & $\infty$
\end{tabular} & 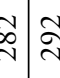 & 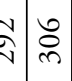 & $\frac{0}{m}$ & 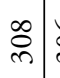 & 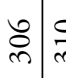 & \begin{tabular}{l|l}
0 \\
$m$
\end{tabular} & 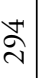 & $\vec{n}$ \\
\hline 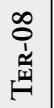 & $\begin{array}{l}\tilde{\sigma} \\
0 \\
0\end{array}$ & 1 & $\begin{array}{l}\tilde{O} \\
0 \\
0\end{array}$ & $\left|\begin{array}{l}n \\
0 \\
0 \\
0\end{array}\right|$ & 1 & 1 & 1 & $\bar{n}$ & $\begin{array}{l}0 \\
0 \\
v \\
v\end{array}$ & 1 & $i$ & $\begin{array}{l}\tilde{0} \\
0\end{array}$ & 1 & $\begin{array}{lll}1 & i \\
0 & 0\end{array}$ & $\begin{array}{l}\infty \\
\stackrel{\infty}{0} \\
0\end{array}$ & & $i$ & 1 & \begin{tabular}{l|l}
0 & 6 \\
0 & 0 \\
0
\end{tabular} & $\begin{array}{l}\hat{0} \\
\hat{n}\end{array}$ & i & $i$ & $\begin{array}{l}1 \\
0 \\
0\end{array}$ & $i$ & $i$ & \\
\hline 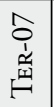 & $i$ & $i$ & $\begin{array}{l}0 \\
\vdots \\
0\end{array}$ & $\mid$\begin{tabular}{c|}
$\vec{F}$ \\
$\overrightarrow{+}$ \\
0
\end{tabular} & $i$ & 1 & $\begin{array}{l}0 \\
0 \\
0\end{array}$ & $\begin{array}{l}n \\
\hat{n} \\
0\end{array}$ & $\begin{array}{c}n \\
\infty \\
0 \\
0\end{array}$ & $\begin{array}{l}\sigma \\
0 \\
0\end{array}$ & $i$ & $\begin{array}{l}\vec{r} \\
0 \\
i\end{array}$ & 1 & $\begin{array}{ll}2 & 1 \\
0 & 1\end{array}$ & 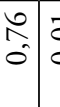 & $\begin{array}{l}5 \\
0 \\
0\end{array}$ & $i$ & $1: \underset{\searrow}{\searrow}$ & \begin{tabular}{l|l}
$\mathbb{E}$ & $\infty$ \\
$0^{\prime}$ & $\infty$ \\
& 0
\end{tabular} & \begin{tabular}{l|l}
$\infty$ & \\
0 & 0 \\
0 & 0 \\
0
\end{tabular} & $i$ & $i$ & i & 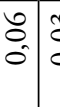 & $\begin{array}{l}0 \\
0 \\
0\end{array}$ & \\
\hline 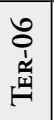 & $\begin{array}{l}+ \\
0 \\
0\end{array}$ & $\begin{array}{l}0 \\
0 \\
0\end{array}$ & $\begin{array}{l}n \\
0 \\
0\end{array} \mid$ & $\left|\begin{array}{l}n \\
0 \\
0\end{array}\right|$ & $\begin{array}{l}0 \\
0 \\
0\end{array}$ & $\begin{array}{l}\overline{0} \\
0 \\
0\end{array}$ & $\begin{array}{l}\tilde{O} \\
0 \\
0\end{array}$ & $\begin{array}{l}1 \\
\infty \\
0^{\prime}\end{array}$ & $\begin{array}{l}\hat{2} \\
\hat{0}\end{array}$ & \begin{tabular}{|l|} 
\\
-1 \\
0
\end{tabular} & $i$ & $\begin{array}{l}\infty \\
\infty \\
0\end{array}$ & 1 & 1 & $\begin{array}{l}n \\
0 \\
0 \\
0\end{array}$ & $i$ & $i$ & \begin{tabular}{l|l}
$\hat{2}$ & 7 \\
0 & \\
0 &
\end{tabular} & \begin{tabular}{l|l}
- & $\infty$ \\
0 & $\infty$ \\
0 & 0
\end{tabular} & \begin{tabular}{l|l} 
& 0 \\
0 & 0 \\
\multirow{2}{*}{} & 0 \\
\end{tabular} & 1 & $i$ & $i$ & $i$ & $i$ & \\
\hline $\begin{array}{l}n \\
0 \\
\frac{1}{y} \\
\text { w } \\
\end{array}$ & $\begin{array}{l}n \\
0 \\
0\end{array}$ & $i$ & $\begin{array}{l}1 \\
\hat{0}\end{array}$ & $\mid \begin{array}{l}\tilde{1} \\
\tilde{0} \\
\hat{n}\end{array}$ & $i$ & 1 & $\begin{array}{l}n \\
0 \\
0\end{array}$ & 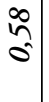 & {$\left[\begin{array}{l}n \\
0 \\
0\end{array}\right.$} & 1 & $\begin{array}{l}0 \\
0 \\
0\end{array}$ & $\begin{array}{c}m \\
\infty \\
\hat{\sim}\end{array}$ & 1 & $1: \frac{2}{1}$ & 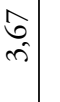 & $i$ & $i$ & $: \begin{array}{l}\checkmark \\
\searrow\end{array}$ & \begin{tabular}{l|l}
$f$ & $\Re$ \\
0 &
\end{tabular} & \begin{tabular}{c|c} 
& 1 \\
$*$ &
\end{tabular} & $\mid \begin{array}{l}0 \\
0 \\
0\end{array}$ & $\begin{array}{l}8 \\
0 \\
0\end{array}$ & $\begin{array}{l}0 \\
0 \\
0\end{array}$ & $i$ & $i$ & \\
\hline 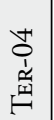 & $i$ & $i$ & $\begin{array}{l}\Omega \\
0 \\
0\end{array}$ & $\begin{array}{l}1 \\
0 \\
0\end{array}$ & i & $\begin{array}{l}\tilde{2} \\
0 \\
0\end{array}$ & $\begin{array}{l}\infty \\
= \\
=\end{array}$ & $\hat{\sigma}$ & $\begin{array}{c}n \\
6 \\
n\end{array}$ & $\begin{array}{l}n \\
0 \\
0\end{array} \mid$ & i & $\begin{array}{l}\tilde{\sigma} \\
\hat{\sim}\end{array}$ & $i$ & $\begin{array}{ll}\tilde{O} & = \\
0 & \\
0\end{array}$ & $\exists$ & $i$ & $i$ & $\begin{array}{l}0 \\
0 \\
0 \\
0\end{array}$ & $: \stackrel{m}{i}$ & $\overrightarrow{2}$ & $\begin{array}{l} \pm \\
0 \\
0\end{array}$ & $\begin{array}{l}2 \\
\vdots \\
0\end{array}$ & $\begin{array}{l}\tilde{\sigma} \\
0\end{array}$ & 1 & $\begin{array}{l}\hat{0} \\
0 \\
0\end{array}$ & \\
\hline 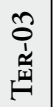 & $i$ & $i$ & $i$ & $\begin{array}{l}+1 \\
0 \\
0 \\
0\end{array}$ & $\begin{array}{l}0 \\
0 \\
0\end{array}$ & 1 & $\begin{array}{l}J^{+} \\
0 \\
0^{\prime}\end{array}$ & 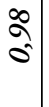 & $\begin{array}{c}\tilde{n} \\
n^{2}\end{array}$ & $\begin{array}{c}\bar{z} \\
0\end{array}$ & $i$ & \begin{tabular}{l|l}
$\because$ & \\
0 &
\end{tabular} & $\begin{array}{l}0 \\
\vdots \\
0\end{array}$ & 17 & $=8$ & 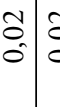 & $\begin{array}{l}\text { त̂ } \\
0 \\
0 \\
0\end{array}$ & 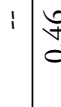 & $\begin{array}{lll}+ & \infty \\
0 & \infty\end{array}$ & \begin{tabular}{l|l}
$\infty$ & 0 \\
-1 & 0 \\
$=$ & 0
\end{tabular} & i & 1 & $\begin{array}{l}n \\
0 \\
0\end{array}$ & $i$ & $i$ & \\
\hline 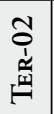 & $\begin{array}{l}\infty \\
0 \\
0 \\
0\end{array}$ & $i$ & $\begin{array}{l}\tilde{O} \\
0 \\
0\end{array}$ & $\mid \begin{array}{l}+ \\
0 \\
0 \\
0\end{array}$ & 1 & $i$ & $i$ & $\begin{array}{l}- \\
- \\
-1\end{array}$ & $\begin{array}{c}0 \\
\vdots \\
m\end{array}$ & $\begin{array}{l}n \\
\tilde{y} \\
0 \\
0\end{array}$ & $i$ & 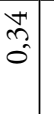 & $i$ & $\begin{array}{lll}1 & y \\
c\end{array}$ & $\begin{array}{l}n \\
\infty \\
0 \\
0\end{array}$ & $i$ & $i$ & \begin{tabular}{l|l}
1 & $\infty$ \\
& $\infty$ \\
& $\infty$
\end{tabular} & \begin{tabular}{l|l}
$\infty$ & $\infty$ \\
$\infty$ & 1 \\
0 & $\infty$
\end{tabular} & $\begin{array}{l}\infty \\
0 \\
0\end{array}$ & 1 & $i$ & $i$ & $i$ & $i$ & \\
\hline 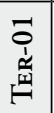 & $i$ & $i$ & 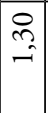 & \begin{tabular}{l|}
1 \\
\hdashline \\
0
\end{tabular} & 1 & $i$ & $i$ & $\underset{\mho}{\mathscr{y}}$ & $\hat{n}$ & 1 & $i$ & \begin{tabular}{l|l}
0 & 1 \\
0 &
\end{tabular} & 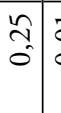 & \begin{tabular}{l|l}
$\tilde{0}$ & \\
0 &
\end{tabular} & $\begin{array}{l}n \\
\tilde{o}\end{array}$ & \begin{tabular}{l}
0 \\
\multirow{+}{+}{} \\
0 \\
0
\end{tabular} & $i$ & 1 & $1: \frac{9}{6}$ & $\begin{array}{l}0 \\
0 \\
0\end{array}$ & $i$ & $i$ & $i$ & $i$ & $i$ & s \\
\hline 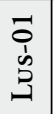 & $i$ & $\begin{array}{l}\overrightarrow{0} \\
0\end{array}$ & $\begin{array}{l}0 \\
0 \\
0\end{array}$ & $=$ & $i$ & $i$ & i & $\begin{array}{l}\tilde{v} \\
\tilde{n}\end{array}$ & $\begin{array}{l}n \\
2 \\
n \\
n\end{array}$ & $\hat{0}$ & i & $\begin{array}{l}\stackrel{+}{2} \\
2 \\
0\end{array}$ & \begin{tabular}{l|l} 
& \\
0 & \\
0
\end{tabular} & \begin{tabular}{l|l} 
& $y$ \\
0 & \\
0 &
\end{tabular} & 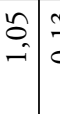 & \begin{tabular}{l|l}
$m$ & $\hat{z}$ \\
0 & \\
0 &
\end{tabular} & 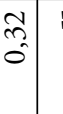 & & 12 & \begin{tabular}{c|l}
2 & 1 \\
&
\end{tabular} & $\begin{array}{l}\overline{0} \\
0 \\
0\end{array}$ & \begin{tabular}{l|l}
$\tilde{O}$ & \\
0 \\
0
\end{tabular} & $\begin{array}{l}n \\
0 \\
0\end{array}$ & 1 & $i$ & \\
\hline$\stackrel{\circ}{z}$ & $\stackrel{\sim}{\sim}$ & $\widehat{\lambda}$ & $\stackrel{\infty}{\sim}$ & নे & mি & $\bar{n}$ & $\pi$ & $m$ & mे & $\tilde{n}$ & ৫) & n & $\stackrel{m}{m}$ & $\hat{m}$ & 아 & $F \circledast$ & $\underset{f}{\sim} \stackrel{\overbrace{}}{\checkmark}$ & $\stackrel{\infty}{f}$ & $\mathbb{F}: \forall$ & 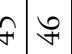 & 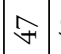 & $\underset{\infty}{\infty} \mid$ & 宁 & 은 & $\vec{n}$ & \\
\hline
\end{tabular}




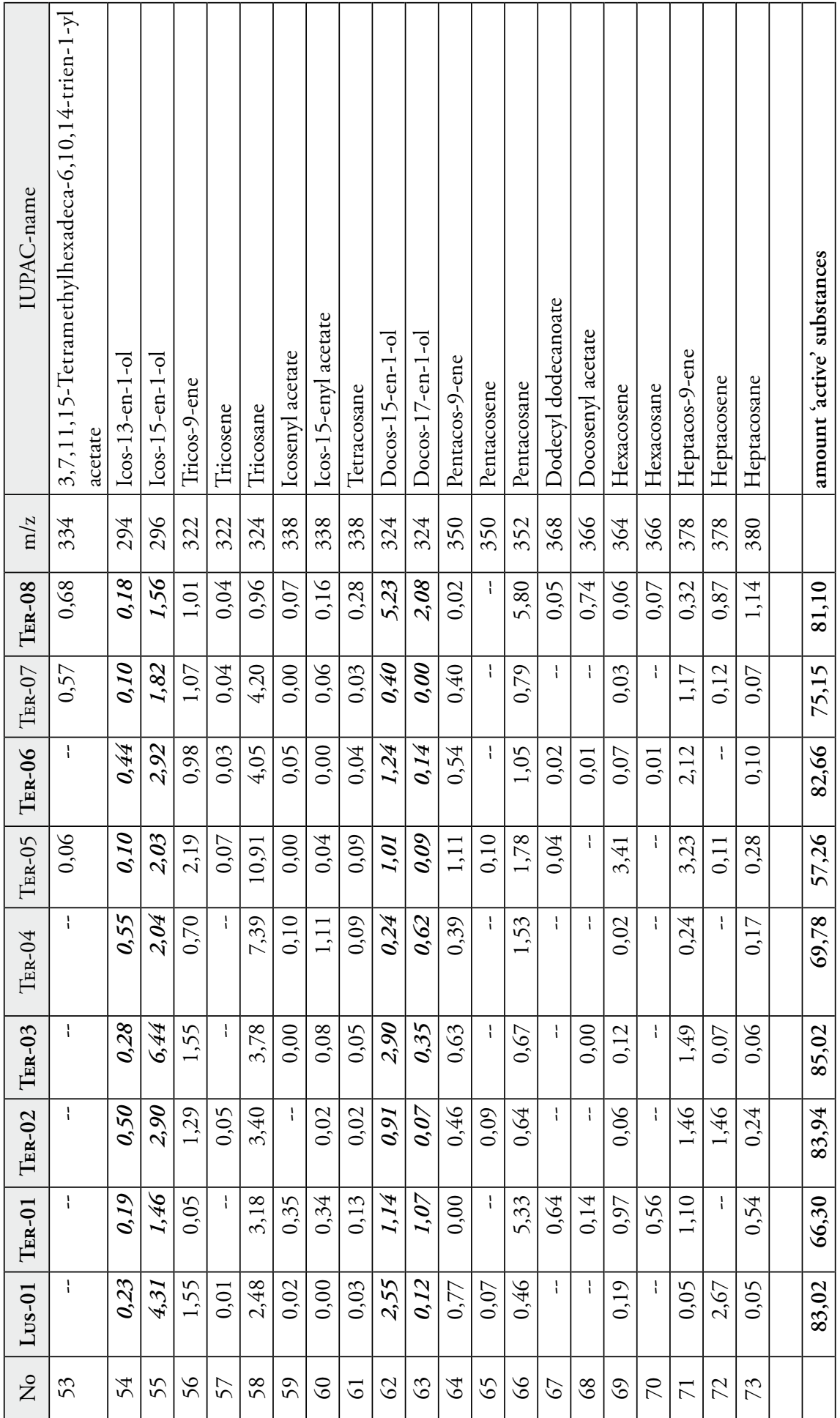




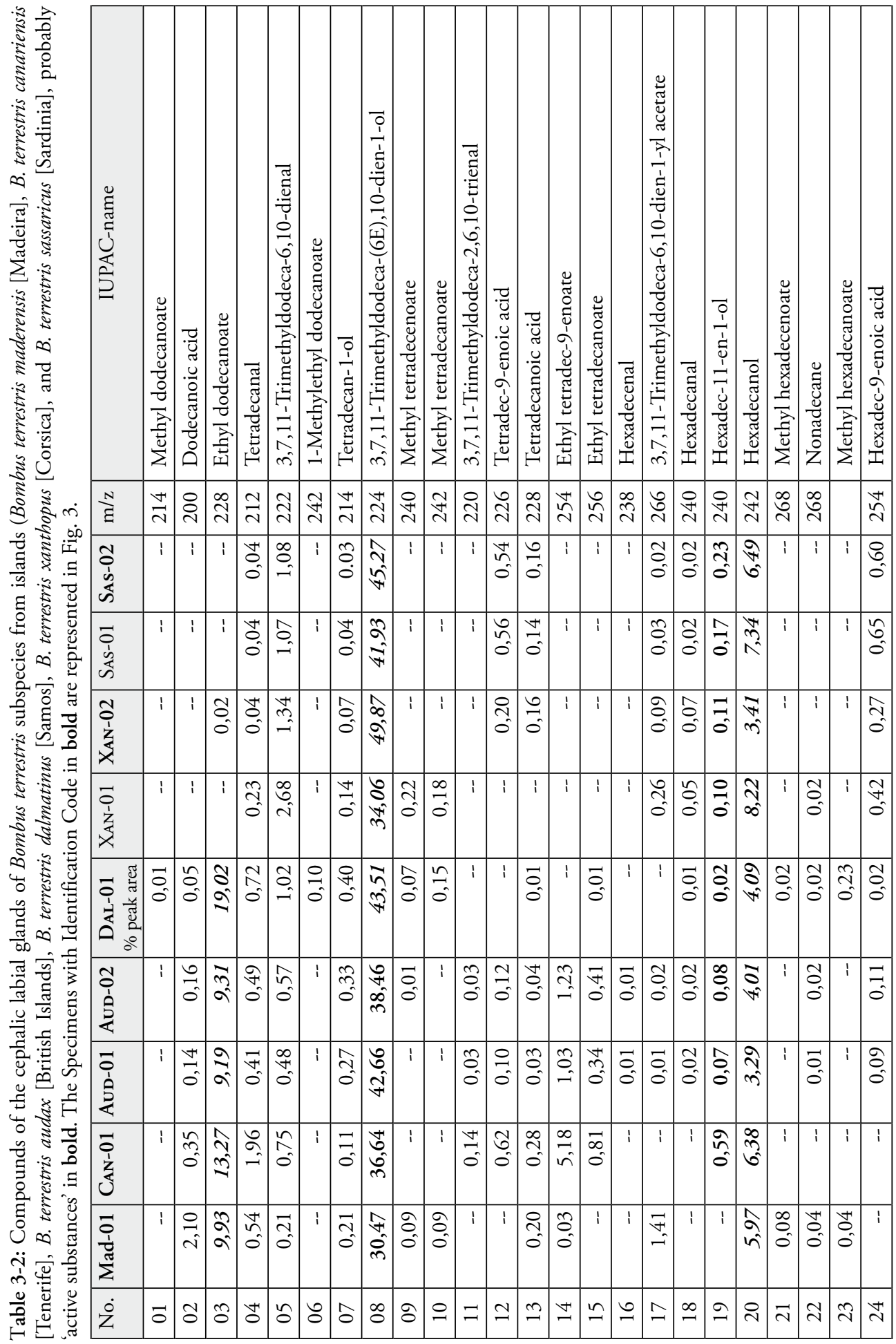




\begin{tabular}{|c|c|c|c|c|c|c|c|c|c|c|c|c|c|c|c|c|c|c|c|c|c|c|c|c|c|}
\hline ๕్ & 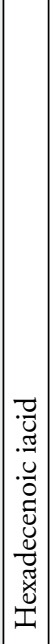 & 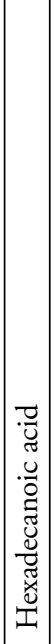 & 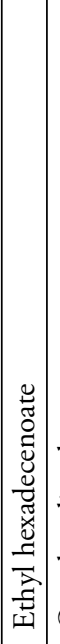 & 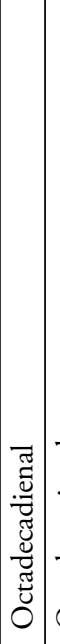 & 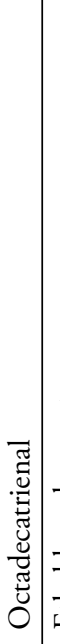 & 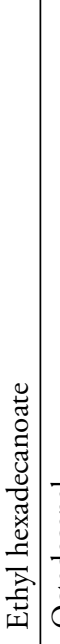 & 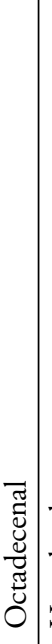 & 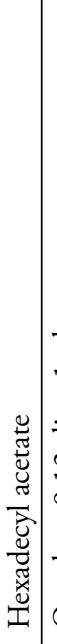 & 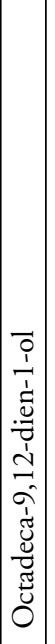 & 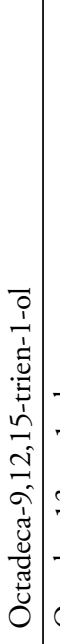 & 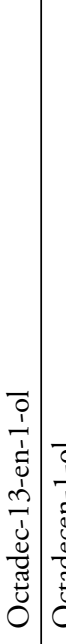 & 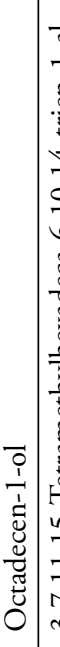 & 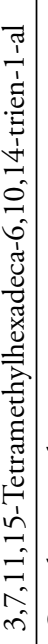 & 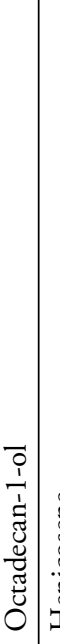 & 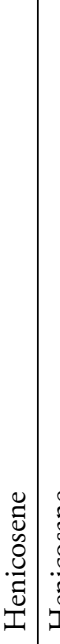 & 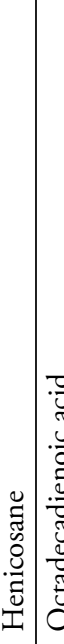 & 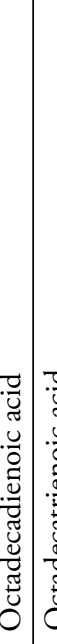 & 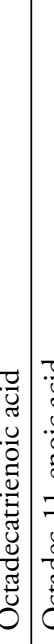 & 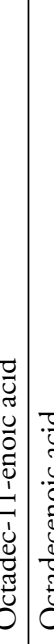 & 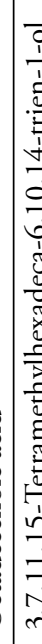 & 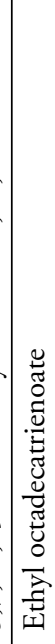 & 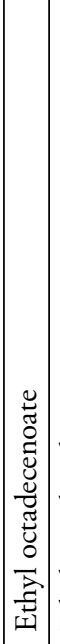 & 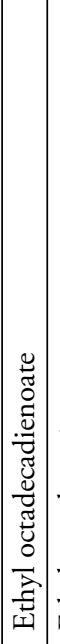 & 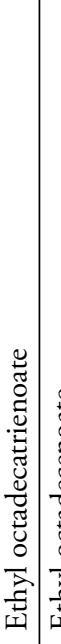 & 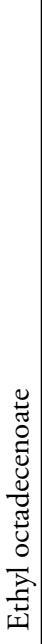 \\
\hline छे & 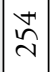 & ڤ̊ & $\mid \begin{array}{c}\sim \\
\infty \\
\sim\end{array}$ & 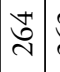 & స్రి & $\underset{\sim}{+\infty}$ & 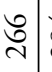 & $\underset{\sim}{+\infty}$ & : & $\underset{\sim}{*}$ & \begin{tabular}{l|l}
$\infty$ \\
$\stackrel{0}{0}$ & \multirow{2}{*}{}
\end{tabular} & 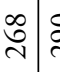 & $\stackrel{\curvearrowright}{\curvearrowright}$ & $\stackrel{尺}{\stackrel{2}{*}}$ & $\stackrel{Ð}{\overparen{\imath}}$ & ৯े & 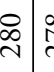 & & $\begin{array}{c}c \\
N \\
N\end{array}$ & ई & ¿ & $\stackrel{0}{\pi}$ & $\begin{array}{l}\infty \\
0 \\
0 \\
\infty\end{array}$ & 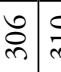 & $\frac{0}{m}$ \\
\hline $\begin{array}{l}\text { ô } \\
\text { ஸे } \\
\text { के }\end{array}$ & $\begin{array}{l}0 \\
\vdots \\
0\end{array}$ & $\mid \begin{array}{l}n \\
0 \\
0 \\
0\end{array}$ & \begin{tabular}{|l|}
1 \\
\end{tabular} & $\mid \begin{array}{l}0 \\
0 \\
0\end{array}$ & \begin{tabular}{l}
\multirow{2}{*}{} \\
$\tilde{0}$
\end{tabular} & $i$ & $\mathrm{i}$ & 1 & $\begin{array}{c}w \\
6 \\
6\end{array}$ & बे & $\begin{array}{l}\tilde{n} \\
\hat{0}\end{array}$ & & $\begin{array}{l}\vec{F} \\
\overrightarrow{0} \\
0\end{array}$ & $i$ & 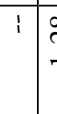 & $\begin{array}{l}\stackrel{\infty}{\mathrm{N}} \\
\rightarrow \\
-\end{array}$ & $i$ & $i$ & $\tilde{\imath}$ & $\forall$ & 1 & $i$ & $i$ & $i$ & $i$ \\
\hline $\begin{array}{l}\overrightarrow{0} \\
\dot{\omega} \\
\text { ڤे }\end{array}$ & $\begin{array}{l}\hat{O} \\
0 \\
0\end{array}$ & $\mid \begin{array}{l}\infty \\
0 \\
0 \\
0\end{array}$ & $i$ & \begin{tabular}{l|l}
0 & \\
0 & \\
0 &
\end{tabular} & 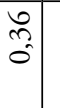 & 1 & 1 & 1 & \begin{tabular}{|l|}
$\mid$ \\
2 \\
$a^{2}$
\end{tabular} & 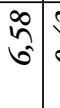 & $\begin{array}{l}\mathfrak{Z} \\
0\end{array}$ & & 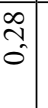 & 1 & 18 & $\infty$ & 1 & $\delta$ & & & & 1 & i & $i$ & $i$ \\
\hline 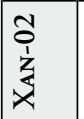 & $i$ & $\begin{array}{l}+ \\
0 \\
0 \\
0\end{array}$ & $i$ & $\begin{array}{l}n \\
\overrightarrow{0}\end{array}$ & $\begin{array}{l}n \\
0 \\
0 \\
0\end{array}$ & : & $\begin{array}{l}+1 \\
0 \\
0\end{array}$ & 1 & $\begin{array}{l}\hat{\kappa} \\
6\end{array}$ & $\begin{array}{l}\infty \\
8 \\
2\end{array}$ & \begin{tabular}{l|l}
$\hat{y}$ & \multirow{2}{c}{} \\
0 & 2
\end{tabular} & 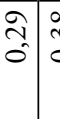 & $\begin{array}{l}\infty \\
2 \\
0 \\
0\end{array}$ & $\begin{array}{l}+ \\
0 \\
0\end{array}$ & i & \begin{tabular}{l|l}
$\infty$ & \multicolumn{1}{c}{} \\
$\infty$ & $\mathbb{C}$
\end{tabular} & $\begin{array}{l}m \\
0 \\
0\end{array}$ & & $\begin{array}{l}\dot{s} \\
0 \\
0\end{array}$ & & 1 & \begin{tabular}{|l|}
$\infty$ \\
0 \\
0
\end{tabular} & \begin{tabular}{l|}
$n$ \\
0 \\
0
\end{tabular} & $\begin{array}{l}\infty \\
0 \\
0\end{array}$ & $i$ \\
\hline $\begin{array}{l}\overline{0} \\
1 \\
z \\
z\end{array}$ & 1 & $\begin{array}{l}1 \\
0 \\
0\end{array}$ & $i$ & ते & $\begin{array}{l}\beth \\
\approx\end{array}$ & 1 & $\begin{array}{l}1 \\
0 \\
0\end{array}$ & 1 & 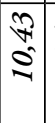 & $\begin{array}{c}8 \\
6 \\
6\end{array}$ & \begin{tabular}{l|l} 
& \\
0 & 2
\end{tabular} & 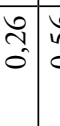 & $\begin{array}{l}0 \\
\mathfrak{n} \\
0 \\
0\end{array}$ & \begin{tabular}{l|l}
0 & \\
0 & \\
0 & \\
\end{tabular} & $\begin{array}{ll}0 & \\
0 & \\
0 & 1\end{array}$ & 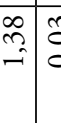 & 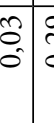 & & $\hat{-}$ & & i & $i$ & $\begin{array}{l}1 \\
0 \\
0\end{array}$ & $\overline{0}$ & i \\
\hline 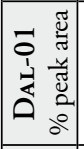 & $i$ & $i$ & $i$ & $\begin{array}{l}\tilde{1} \\
0 \\
0\end{array}$ & $\begin{array}{c}\stackrel{1}{c} \\
0 \\
\end{array}$ & $\begin{array}{l}0 \\
0 \\
0\end{array}$ & $i$ & 1 & $\begin{array}{c}\widehat{N} \\
-\hat{\sim}\end{array}$ & $\begin{array}{l}\mathfrak{w} \\
\mathfrak{v}\end{array}$ & 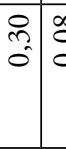 & \begin{tabular}{l|l}
$\infty$ & \multicolumn{2}{c}{} \\
0 & 2 \\
0 &
\end{tabular} & $\begin{array}{l}0 \\
0 \\
0\end{array}$ & 1 & \begin{tabular}{l|l}
$\tilde{\sigma}$ & 1 \\
0 & 1
\end{tabular} & 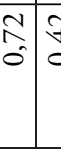 & \begin{tabular}{l}
7 \\
\multirow{2}{*}{} \\
0
\end{tabular} & $i$ & i & & 1 & 1 & 1 & $i$ & i \\
\hline 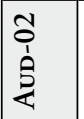 & i & i & $i$ & $\begin{array}{l}\overrightarrow{0} \\
0\end{array}$ & i & $i$ & $\begin{array}{l}\overrightarrow{0} \\
0\end{array}$ & 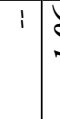 & $\begin{array}{c}0 \\
\vdots \\
-1\end{array}$ & $\begin{array}{c}\tilde{O} \\
\dot{n} \\
\dot{2}\end{array}$ & \begin{tabular}{l|l}
$\mathfrak{n}$ & 2 \\
0 & 0
\end{tabular} & \begin{tabular}{l|l}
- & 1 \\
0 & \\
0
\end{tabular} & $\begin{array}{l}0 \\
0 \\
0 \\
0\end{array}$ & $\begin{array}{l}\hat{\theta} \\
0 \\
0\end{array}$ & $\begin{array}{l}\sigma_{0} \\
0 \\
0\end{array}$ & $\underset{\Xi}{\beth}$ & i & $\begin{array}{l}\infty \\
0 \\
0 \\
0\end{array}$ & ? & 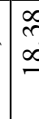 & $i$ & i & $\frac{N}{0}$ & $\overline{0}$ & \\
\hline \begin{tabular}{l}
0 \\
0 \\
1 \\
0 \\
\multirow{2}{*}{}
\end{tabular} & $i$ & $i$ & $i$ & \begin{tabular}{l|l} 
& \\
0 & \\
0 &
\end{tabular} & $\begin{array}{l}n \\
0 \\
0\end{array}$ & 1 & 1 & 8 & $\begin{array}{l}2 \\
\text { के } \\
0\end{array}$ & $\begin{array}{l}2 \\
m \\
m\end{array}$ & $\tilde{\tilde{z}}$ & & $\begin{array}{l} \pm \\
\vdots \\
0 \\
0\end{array}$ & $\begin{array}{l}n \\
0 \\
0\end{array}$ & 1 & ஜ & $i$ & $\begin{array}{l}\hat{0} \\
\text { O. }\end{array}$ & $\frac{1}{0}$ & g & $\begin{array}{l} \pm \\
0 \\
0\end{array}$ & 1 & i & $\mathrm{i}$ & i \\
\hline 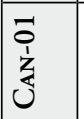 & 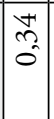 & $\frac{n}{0}$ & 1 & i & $i$ & 1 & 1 & 8 & \begin{tabular}{|c|} 
\\
\multirow{2}{*}{} \\
0 \\
0
\end{tabular} & $\begin{array}{l}6 \\
6 \\
6\end{array}$ & $\begin{array}{l}\approx \\
0 \\
0\end{array}$ & $i$ & 1 & $\begin{array}{l} \pm \\
\vdots \\
0\end{array}$ & 7 & $\stackrel{\sharp}{\Rightarrow}$ & 1 & $\begin{array}{l}\hat{\tilde{z}} \\
\hat{\sigma}\end{array}$ & ? & & i & 1 & i & $\mathrm{i}$ & i \\
\hline $\begin{array}{l}0 \\
\frac{1}{0} \\
\frac{\pi}{\sigma}\end{array}$ & $i$ & $\begin{array}{l}0 \\
0 \\
0\end{array}$ & & $\begin{array}{c}n \\
\infty \\
0\end{array}$ & 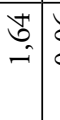 & \begin{tabular}{ll}
8 & \multicolumn{1}{c}{} \\
0 &
\end{tabular} & $\begin{array}{l}\approx \\
\overrightarrow{0} \\
0\end{array}$ & $\tilde{\tilde{c}}$ & 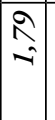 & 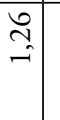 & 1 & \begin{tabular}{l|l}
1 & 5 \\
& 5
\end{tabular} & $\begin{array}{l}n \\
\\
n\end{array}$ & $i$ & $\begin{array}{lll}n & 1 \\
0 & 1 \\
0 & 1\end{array}$ & $\stackrel{n}{\approx} \underset{\sim}{\approx}$ & $i$ & 1 & $\hat{2}$ & in & $\frac{m}{0}$ & $\begin{array}{l}\hat{\sigma} \\
\hat{0}\end{array}$ & 1 & i & i \\
\hline & $\mathrm{v}$ & $\stackrel{\sim}{2}$ & $\hat{\imath}$ & $\mid \begin{array}{l}\infty \\
\sim\end{array}$ & $\grave{\curvearrowright}$ & ஜ) & $\vec{n} \mid$ & $\approx$ & 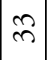 & $\vec{m}$ & $\approx$ & \begin{tabular}{l|r} 
\\
$m$
\end{tabular} & के & $\stackrel{\infty}{\infty}$ & ले & 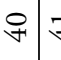 & $F$ & $\stackrel{\sim}{+}$ & f & F & 나 & $\ngtr$ & $\stackrel{\infty}{+}$ & શे & \\
\hline
\end{tabular}




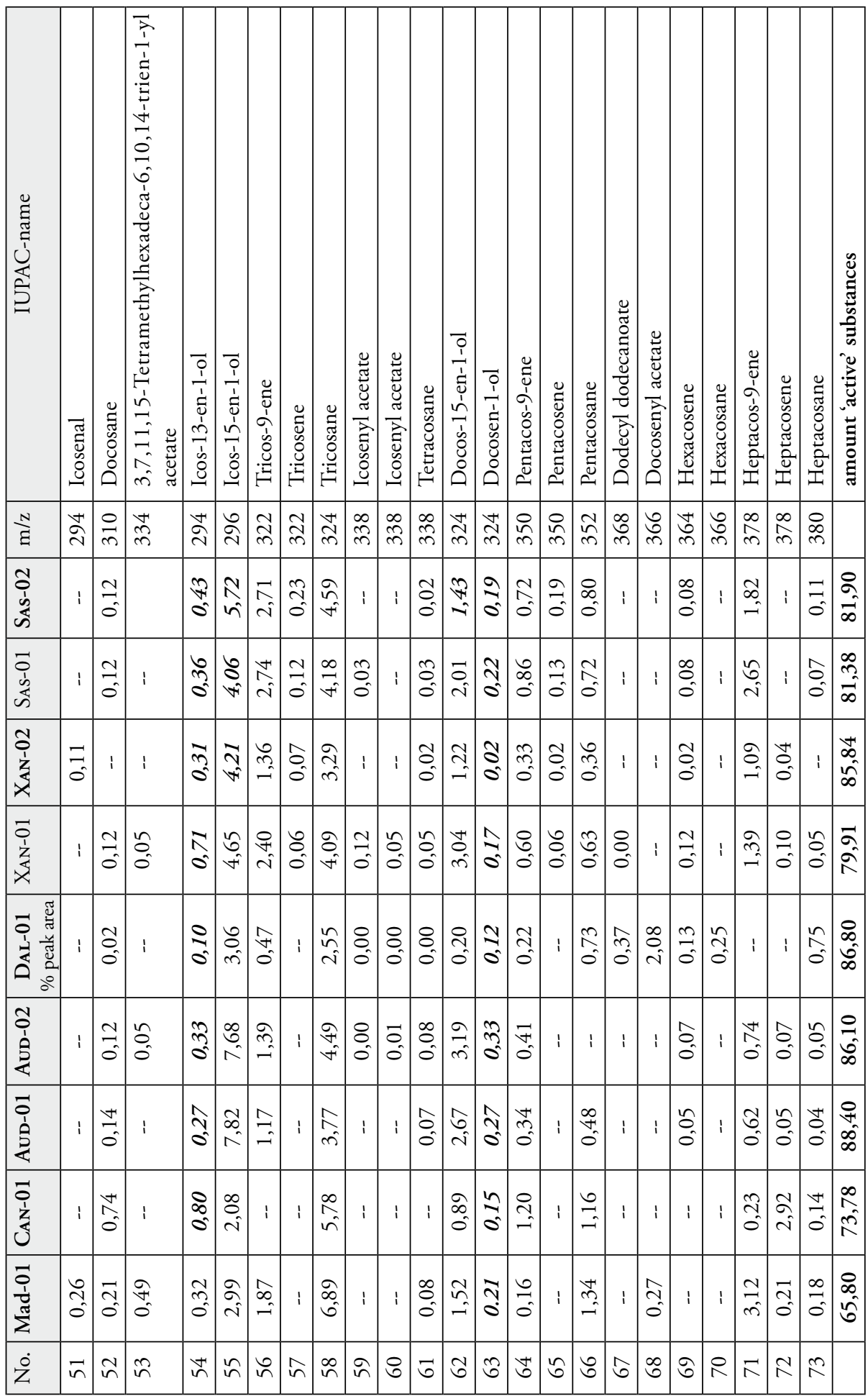




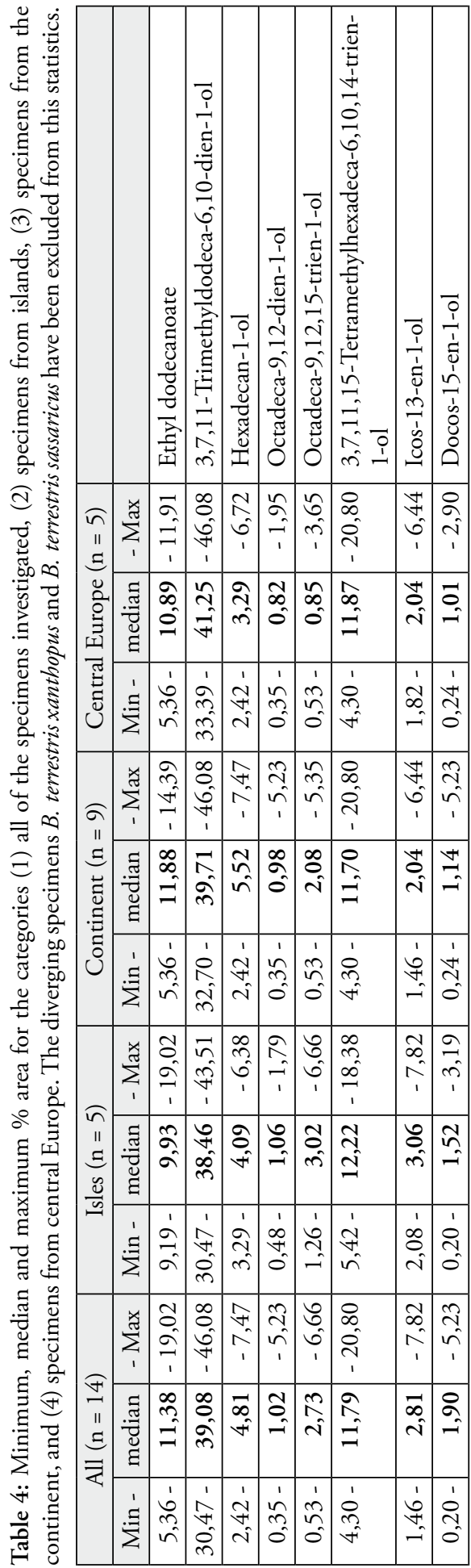
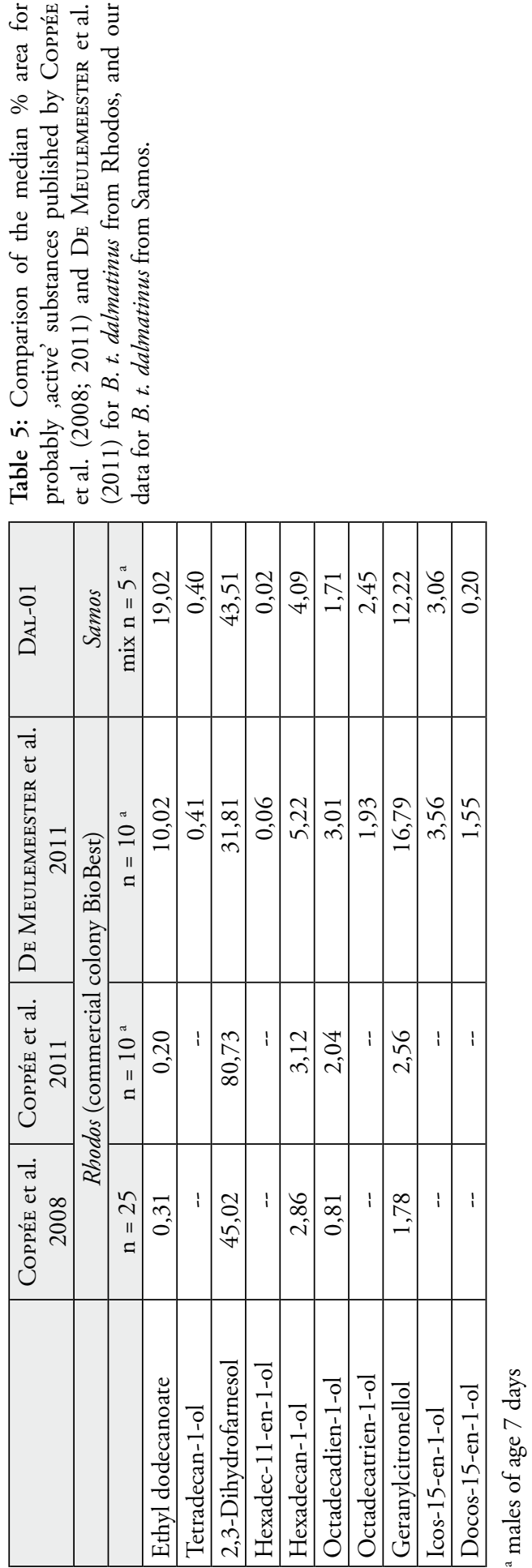